\title{
WHY 'DEMOCRACY' AND 'DRIFTER' FIRMS CAN HAVE ABNORMAL RETURNS: THE JOINT IMPORTANCE OF CORPORATE GOVERNANCE AND ABNORMAL ACCRUALS IN SEPARATING WINNERS FROM LOSERS*
}

\author{
KOON BOON KEE ${ }^{* *}$ \\ Singapore Management University
}

\begin{abstract}
This study is the first to investigate the complementarity relationship of governance and earnings quality (EQ) over the period of 1991-2008. Firstly, the governance effect on performance is overrated without good EQ, as measured by the magnitude of abnormal accruals (AA), as an input. Isolating good governance (Democracy) firms with Low AA generates a positive abnormal return of 10.5 percent per year. Secondly, Democracy firms with High AA have positive abnormal future returns, contrary to Sloan (1996). Overall, the results highlight the joint importance of governance and AA in contributing to the total information environment to separate winners from losers.
\end{abstract}

Keywords: corporate governance, abnormal accruals, earnings quality, contextual information, returns predictability, special items.

\section{NEDEN 'DEMOKRASI' (DEMOCRACY) SIRKETLERI VE ''BAŞIBOŞ' (DRIFTER) ŞIRKETLER NORMALÜSTÜ KAR ELDE EDEBILIIRLER: KAZANANLARI KAYBEDENLERDEN AYIRT ETMEK IÇİN KURUMSAL YÖNETIM VE NORMALÜSTÜ TAHAKKUKLARIN ORTAKLAŞA TAŞIDIKLARI ÖNEM}

\section{ÖZET}

Bu çalışma 1991-2008 döneminde kurumsal yönetim ve gelirlerin raporlanma kalitesinin (EQ) birbirini tamamlayıcı ilişkisini inceleyen ilk çalışmadır. Öncelikle, normalüstü tahakkuk (AA) büyüklü̈̆̈̈ ile ölçülen yüksek bir EQ'yu bir girdi olarak kullanmadan yapılan bir ölçümde, kurumsal yönetimin performans üzerindeki etkisine fazla de ğer yüklenmiş olur. Sadece düşük AA'sı ve iyi kurumsal

* The author is grateful to Jeremy Goh, Chih-Ying Chen, Chiraphol New Chiyachantana, and Kwong Sin Leong for their valuable comments and help. In addition, the author would like to thank Kevin Ow Yong, Chee Yeow Lim, Yoonseok Zang, Young Koan Kwon, Alexander Niessen-Ruenzi, the brown bag seminar participants in the School of Accountancy and the Lee Kong Chian School of Business at Singapore Management University, and the participants at the $23^{\text {rd }}$ Australasian Finance and Banking Conference for their helpful feedback. All errors are my own.

** Koon Boon Kee is a lecturer in the School of Accountancy at Singapore Management University, 60 Stamford Road, Level 4 Room 4019, Singapore 178900, and is also the Managing Director at Aegis Group Companies. E-mail: kbkee@aegisgc.com 


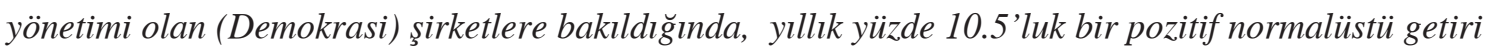
görmekteyiz. İkinci olarak, Sloan (1996) bulgularının aksine, yüksek AA'sı olan demokrasi sirketleri gelecekte pozitif normalüstü karlar elde etmektedirler. Genel olarak bakıldı̆̆ında ise, sonuçlar, kazananların kaybedenlerden ayırt edilebilmesinde kurumsal yönetim ve AA'nın bütünsel bilgi ortamına müşterek olarak yaptıkları katkının önemini göstermektedir.

Anahtar kelimeler: kurumsal yönetim, normalüstii tahakkuklar, gelir raporlama kalitesi, bağlamsal informasyon, kar öngörülebilirliği, özel kalemler (hesaplar).

Investors willingly entrust their capital to managers on the assurance that the self-serving managers will exercise their discretionary rights appropriately to increase shareholders' wealth and not expropriate their assets for their own profit. Managerial discretion can be used to make reported earnings a precise signal of firm value and managerial performance, enhancing the value of accounting as a language to communicate with the investors. Consequently, the allocation and utilization flow of capital is made more responsive since financial accounting information provides investors with an important source of information to help them better evaluate the relative health and worth of the enterprise and to make better investment decisions. However, managerial discretion can also be used to engage in earnings management to conceal poor performance or to exaggerate good performance, either for career concerns or compensation reasons. Healy (1996) termed the former motive to be the Performance Measurement (or Efficient Contracting) Hypothesis, and the latter to be the Opportunistic Hypothesis.

Accruals in accounting are estimates of future cash realizations, with considerable room for managerial discretion in their reporting. Most accruals reverse when the cash consequences they anticipate are realized and the subsequent realization of the cash has no impact on earnings. However, since accruals are estimates of expected future cashflows, the original accrual may not always equal the subsequent cash realization. In such cases, the difference between the original accrual and the associated future cash realization must be recognized in future earnings. Since the intriguing results in the seminal paper by Sloan (1996) that high or income-increasing (low or income-decreasing) accruals are related to negative (positive) future stock returns, evidence of high or income-increasing accruals have been widely interpreted and justified as bookkeeping mischief and a signal of low earnings quality (EQ), in favor of the Opportunistic Hypothesis. For instance, a big increase in inventory accruals is interpreted as signalling a greater likelihood that inventories overstate their associated future benefits, and implying a greater likelihood of subsequent inventory write-downs to be reflected in future earnings.

Yet, accruals may also serve as leading indicators of changes in a firm's prospects, without any manipulation by managers. Since management presumably has superior information about the firm's cash generating ability, the discretion provided by GAAP in estimating accruals can be used by management to signal their private information to investors, so that reported earnings will more closely reflect firm performance than realized cashflows (Holthausen and Leftwich, 1983; Watts and Zimmerman, 1986; Holthausen, 1990; Healy and Palepu, 1993; Subramanyam, 1996; Bartov, Givoly, and Hayn, 2002). Thus, a credible signal will reduce information asymmetry, in support of the Performance Management Hypothesis. Given the overwhelming support of the Opportunistic Hypothesis, management is deemed to have nefarious intentions for purchasing inventory above beginning inventory levels even if this was a positive net present value decision. Joshua Livnat, accounting professor at the New York University's Stern School of Business commented that "I don't think you can use accruals to decide whether management is acting in the best interests of 
shareholders," and that he is "usually not happy second-guessing management or attributing to them a lot of sinister motives" (Trammell, 2010: 40).

As the output of financial accounting information is produced by management, it suggests that good governance structure, which mitigates agency costs and is shown to be important in determining firm value in the influential paper by Gompers, Ishii, and Metrick (GIM, 2003), is necessary to ensure that the accounting information supplied by management is not opportunistically manipulated in response to a variety of incentives, and hence the signals produced by management can be reliably assessed by external parties. The output of EQ, in turn, serves as an input to better governance structures and corporate control mechanisms to improve the productivity of investments through three channels: one, by increasing the efficiency with which the assets in place are managed (governance channel); two, by reducing the error with which managers identify good versus bad investments (project identification); and three, by reducing the information asymmetries among investors and the expropriation of investors' wealth (adverse selection) (Bushman and Smith, 2001; Sloan, 2001).

Thus, it is clear that corporate governance and financial accounting are inexorably linked through a complementarity relationship. Complementarity, as pointed out by Ball, Jayaraman and Shivakumar (2010), implies that "financial reporting usefulness depends on its contribution to the total information environment, whereas substitutability implies that usefulness depends on the new information it releases on a stand-alone basis." Thus, both governance and accruals information are jointly informative; each may contain information not contained in the other about the future prospects of the firm. Importantly, this suggests the possibility of two previously unexamined relationships that will be explored further in this paper.

Firstly, I posit that governance could be overrated without abnormal accruals (AA) as an input. The results in GIM (2003) indicate that the hedge portfolio of buying firms with strong governance (Democracy), and selling firms with weak governance (Dictatorship), can generate significant longterm abnormal return of $8.5 \%$ per year over the sample period from September 1990 to December 1999. The hedge returns are asymmetrically positioned, with 3.5 (5.0)\% from the long (short) position of the Democracy (Dictatorship) firms. In particular, I argue that it is possible that the good governance associated with future positive abnormal stock returns could be attenuated when the subset of Democracy firms with low or extreme income-decreasing AA is removed. Thus, good governance per se does not lead to future positive abnormal return, contrary to the findings in GIM (2003). In other words, good governance on a stand-alone basis no longer pays off. Isolating the Democracy firms with Low AA should also enhance significantly the governance effects on future positive abnormal return. In addition, mixed governance (Drifter) and Dictatorship firms with Low AA should have a positive abnormal return.

In support of this view, with AA estimated as the residual in the Dechow and Dichev (2002) model, I find evidence that removing firms with low or extreme income-decreasing AA will reduce the Democracy portfolio return to no different from zero statistically over the period of 1991-2008, and over the sub-period of 1991-1999 that was examined in GIM (2003). In addition, the portfolio of Democracy firms with Low AA generates a positive abnormal return of 10.5\% per year from 1991 to 2008, which is not only economically larger (700 basis points) than the long position documented in GIM (2003), but is also 200 basis points more than the entire hedge return. In addition, the incremental value in the good governance and Low AA signal yields 3.9 and 7.0\% abnormal return per year respectively. 
Specifically, these Democracy-Low AA firms (dubbed Super-Performers) significantly outperform the unconditional Low AA (Democracy) firms, revealing incremental value in the good governance (Low $A A)$ signal, thus lending weight to the intuition behind a complementarity relationship between the two signals. Interestingly, some of these Super-Performers include well-known, institutional big-cap stocks, such as Coca-Cola Co, AT\&T, Hewlett-Packard, Wyeth, Nordstrom, Lowe's, Home Depot, and EMC, formed in the portfolio at various months in the sample period. Drifter firms with Low $A A$ deliver abnormal return at $6.2 \%$ per year; Dictatorship firms with Low AA have positive, albeit statistically insignificant, abnormal return.

Of great interest and debate in the literature is the question of whether investors are able to "see through" transitory distortions in accrual accounting numbers. The explanation by Sloan is that investors are thought to be overly-fixated on earnings (the Earnings-Fixation Hypothesis), misinterpreting the transitory nature of the accruals information, only to be systematically surprised when accruals turn out, in the future, to be less persistent than cashflows. Consequently, abnormal stock returns result as corrections to the initial overreaction in the year immediately following extreme accruals. Thus, Sloan views future reversals to be a result of aggressive or "bad" accounting that originally inflate accruals. Accordingly, a hedge portfolio that buys (sells) firms with low (high) accruals can generate annualized abnormal return of $10.4 \%$, with 4.9 (5.5)\% from the long (short) position in the subsequent year. Further evidence by Xie (2001), DeFond and Park (2001), and Chan et al. (2006) indicate that this "accruals anomaly" is related to abnormal, sometimes called discretionary, accruals. They argue that certain discretionary actions on the part of managers induce a transitory element to accruals, with a stronger mean-reverting tendency of discretionary accruals, defined using the Dechow et al. (1996) modified Jones model, leading to an overpricing of aggregate accruals. However, a limitation of Sloan's study is that the returns predictability could be attributed to unidentified risk factors that are correlated with accruals or unknown research design flaws (Kothari, 2001). Healy (1996) pointed out that one major deficiency is the inability of these accruals models to "adequately incorporate the effect of changes in business fundamentals." Healy and Whalen (1999) also highlighted their inadequacy to "further identify and explain which types of accruals are used for earnings management and which are not."

Therefore, and secondly, I argue that the conventional interpretation of EQ, measured by the magnitude of abnormal accruals, could vary across governance structures. The uncertainty associated with the abnormal accruals signal - that is, managerial discretion could be interpreted as either opportunistic or conveying credible private signal about firm performance - is interactively resolved with information about the firm's governance structure, and the unique pairing of the signals contains unique information about the future prospects of the firm. Abnormal accruals, when accompanied by good governance, become more informative and the interactive combined signal corroborates the Performance Management Hypothesis. In particular, firms with high or extreme income-increasing AA, usually interpreted as evidence of earnings management, will not have negative future abnormal returns if they happen to be also Democracy firms, contrary to the predictions in Sloan (1996). Such an interpretation will be strengthened in an additional test if there is evidence such that when the portfolio of firms with revelation of high or extreme income-increasing accruals in period $t$ experiences the biggest magnitude in accruals reversal in period $t+1$, those who are also Democracy firms will have positive future abnormal return, not negative return as was predicted under Sloan's hypothesis. The trend of reported earnings and the subsequent accruals reversals at these firms are interpreted as credible private signals of firm performance by the managers, resulting in larger positive future 
stock returns, as it has been shown that the earnings trend consistency is valued at a premium by the market (Barth, Elliott, and Finn, 1999), as is consistency in benchmark performance (Bartov et al., 2002; Kasznik and McNichols, 2002; Koonce and Lipe, 2010). Firms with extreme income-increasing accruals, when accompanied by Dictatorship and Drifter governance structures, have negative future stock returns, consistent with Sloan's predictions.

Corroborating evidence indicates that firms with high or extreme income-increasing AA and who are also Democracy firms have positive, albeit insignificant, annualized abnormal return of 3.2\% per year over the 1991-2008 period. In addition, the portfolio of stocks with revelation of high or extreme income-increasing accruals in period $t$ and with the greatest magnitude in accruals reversal in period $t+1$, and who are also Democracy firms, have positive annualized abnormal return of $10.8 \%$. Unsurprisingly, firms with high or extreme income-increasing AA with Dictatorship and Drifter governance structures have negative abnormal annualized returns of 0.9 and $7.5 \%$ respectively, as predicted by Sloan (1996).

The viewpoint in Sloan (1996) that high accruals are associated with negative future stock returns has far-reaching consequences, suggesting that it may be necessary to limit managers' discretion with respect to accounting accruals, since investors cannot unravel the valuation effect of reported earnings in a timely manner under current reporting standards. Such an interpretation may be premature. My results raise doubts that investors respond in the same manner to abnormal accruals, since Democracy firms with high or extreme income-increasing AA have positive future returns. This suggests two things: one, the level of abnormal accruals is a coarse measure of earnings manipulation for these sets of firms, although it appears to remain a reasonable proxy of earnings management or EQ for firms with mixed or poor governance structures; and two, their shareholders benefit from "earnings management" because the high or extreme income-increasing accruals signal future performance (e.g. Subramanyam, 1996; Chanel et al., 1996). The evidence helps in the understanding of investor behavior and whether the policy recommendations in Richardson et al. $(2005,2006)$ and FASB to curtail the use of "less reliable" components of accruals are appropriate, especially for the Democracy firms. If the joint interactive signal of governance and abnormal accruals can be a more informative measure of firm performance, reforms to limit managerial flexibility may be counterproductive.

This paper can be viewed as an attempt to integrate two streams of research in financial accounting and finance. The first stream consists of a long string of papers, sparked by the influential GIM (2003), which examines the governance effects on firm performance. The second stream consists of valuationoriented papers, because of the seminal paper by Sloan (1996), which shows that accruals predict future returns. Overall, the results in the two previously unexamined relationships highlight the joint importance of governance and abnormal accruals in contributing to the total information environment to separate winners from losers.

The rest of the paper is organized as follows. Section 2 reviews the literature and develops the hypotheses. Section 3 describes the data, variable description and construction, and research methodology. Section 4 presents the empirical results, while Section 5 looks at the robustness test. Section 6 concludes the paper. 


\section{LITERATURE REVIEW AND HYPOTHESES DEVELOPMENT}

"Financial statements are a central feature of financial reporting - a principal means of communicating financial information to those outside an entity" (FASB, 1984: paragraph 5).

"Future research can also contribute additional evidence to further identify and explain which types of accruals are used for earnings management and which are not. Future research is also needed to determine the conditions in which discretion in financial reporting is primarily used to improve communication vs. manage earnings" (Healy and Whalen, 1999: 368).

Agency costs, which result from the separation of management and financing, come in many guises. Managers may shirk or waste resources, invest extravagantly, build empires to the detriment of shareholders, and engage in self-dealing behavior such as consuming perks and generating private benefits (Jensen and Meckling, 1976; Jensen, 1986; Djankov et al., 2008). Managers may also seek to entrench themselves by designing complex cross-ownership and holding structures with double voting rights that make it hard for outsiders to gain control (Demsetz and Lehn, 1985; Ang, Cole, and Lin, 2000; La Porta et al., 2000; Gompers, Ishii, and Metrick, 2010), or by routinely resisting hostile takeovers, as these threaten their long-term positions (GIM, 2003; Bebchuk, Cohen, and Farrell, 2009).

Information asymmetries between management and financiers create a demand for an internally generated measure. This may be an early or timely signal of firm performance needing to be reported for stewardship assessments that is not yet garbled by the future environmental noise that accumulates after the signal is revealed but before the final outcome is realized. Financial accounting information is an important source of information and firm output on firm performance for ex ante resource allocation decisions. Standard setters define the accounting language that management uses to communicate with the firm's external stakeholders. By creating a framework that independent auditors ${ }^{(1)}$ and the SEC can enforce, accounting standards can provide a relatively low-cost and credible means for corporate managers to report information on their firms' performance to external capital providers and other stakeholders (Healy and Whalen, 1996). Ideally, financial reporting therefore helps the bestperforming firms (winners) in the economy to distinguish themselves from poor performers (losers) and facilitates efficient resource allocation and stewardship decisions by stakeholders.

Over finite intervals, reporting realized cash flows is not necessarily informative because realized cash flows have timing and matching problems that cause them to be a "noisy" measure of firm performance. Accounting accruals, guided by the revenue recognition and matching accounting principles, overcome this problem that comes from measuring firm performance when firms are in continuous operations. They accomplish this by altering the timing of cashflow recognition in earnings. Invented in 1494 by a Franciscan monk named Luca Pacioli, accruals accounting was designed to be the "nerve cell" to help the flourishing Venetian merchants manage their burgeoning economic empires and to serve as a communication tool with external parties. Dechow (1994) provides evidence that accrual accounting earnings are superior to cash accounting earnings at summarizing firm performance.

Yet, as financial accounting information is a managerial output, management has discretion over the level of accruals (McNichols and Wilson, 1988). Since the seminal paper by Sloan (1996) documenting the influential result that high accruals are associated with negative future returns, most literature has held a scathing view of the role of accounting accruals as a discretionary device allowed under GAAP. 
The reason is that such accruals give managers the flexibility to manage earnings opportunistically, allowing them to entrench themselves (Shleifer and Vishny, 1989), either for career concerns (Murphy and Zimmerman, 1993; Pourciau, 1993; Smith, 1993; Farrell and Whidbee, 2003) or for compensation reasons (Matsunaga, 1995; Balsam, 1998; Matsunaga and Park, 2001; Bartov and Mohanram, 2004; Cheng and Warfield, 2005; Bergstresser and Philippon, 2006; Burns and Kedia, 2006; Cornett et al., 2007). The evidence shows in particular popular anecdotes of earnings management in wellpublicized accounting scandals such as Enron and WorldCom. Thus, while accrual accounting is superior to cash accounting in summarizing performance, the accrual component of earnings should receive a lower weight than the cash component of earnings in evaluating firm performance, due to the greater subjectivity involved in the estimation of accruals. This interpretation was reinforced by an earlier paper by Dechow et al. (1995) who carried out an ex post analysis of a sample of earnings manipulations subject to SEC enforcement actions. They found that those earnings manipulations are primarily attributable to accruals that reverse in the year following the earnings manipulations. As a result of this interpretation, the use of abnormal accruals as a proxy of earnings management or earning quality is prevalent in a long list of literature (for examples, see the survey paper on earnings quality by Dechow, Ge, and Schrand, 2009).

However, accounting discretion in accruals can be used by management, whose superior information about their firm's cash generating ability can signal their private information (Beaver et al., 1989; Wahlen, 1994; Subramanyam, 1996; Beaver and Engel, 1996; Arya et al., 2003; Louis and Robinson, 2005) in order to enhance their credibility and reputation (Desai et al., 2006) and maximize the shareholders' wealth as efficient contracting would suggest (e.g. Malmquist, 1990). Also, an earnings trend consistency is valued at a premium by the market (Barth, Elliott, and Finn, 1999), as is consistency in benchmark performance (Bartov et al., 2002; Kasznik and McNichols, 2002, Koonce and Lipe, 2010). Skinner and Sloan (2002) showed that when a firm's earnings fall short of the analyst consensus forecast by even a small amount, it triggers a large negative stock price reaction. In addition, managers can manage earnings to avoid violating accounting-based debt covenants that would otherwise increase the cost of capital for the firm (Watts and Zimmerman, 1986, 1990; Smith, 1993; Sweeney, 1994). Managing earnings "appropriately" to smooth earnings ${ }^{(2)}$ can "save" current earnings for possible use in the future (DeFond and Park, 1997), thus increasing the informativeness of future earnings (Tucker and Zarowin, 2006); reduce the variability in reported earnings more when firms operate in high uncertainty (Ghosh and Olsen, 2009); and portray a less risky image of the firm (Gul et al., 2003) by reducing the perceived bankruptcy probability of the firm and, hence, the firm's borrowing cost (Trueman and Titman, 1988). These actions that smooth the earnings can be beneficial to the firm's shareholders (Goel and Thakor, 2003). Demski (1998) argued that managers communicate acquired expertise through such earnings smoothing. Chaney, Jeter, and Lewis (1996) suggest that discretionary accruals smooth earnings and they interpret their findings as evidence that discretionary accruals are not opportunistic but rather that they communicate information about the firm's long-term (permanent) earnings to equity markets.

Accounting accruals also serve as an input to help curb the agency problems, and to better governance structures and corporate control mechanisms, again in order to improve the productivity of investments (Bushman and Smith, 2001; Sloan, 2001). Accounting information can be used to indicate whether governance actions against management are required. For instance, the board uses accounting earnings performance as an input into their firing decisions (Weisbach, 1988). Managers also may not wish to inflate accruals since they are associated with heightened litigation risk (Dechow et al., 1996; DuCharme et al., 2004). 
Still, we do not have sufficient and conclusive evidence on whether managers exercise accounting discretion in an opportunistic or efficient manner (Dechow et al., 2009), which has been one of the long-standing questions of positive accounting research (Watts and Zimmerman, 1978, 1990). There is a missing "deciphering key" that does not allow the contracting manager to describe ex ante the meaning of "good performance." It is only later when the uncertainty unfolds that it becomes clearer what a good performance means. If accounting discretion in reporting firm performance could be abused by managers to entrench themselves for job security or compensation reasons, then it is possible that the effectiveness of internal controls, which include efficient contracting mechanisms that seek to align managerial interests with those of the shareholders, could curb these miscreant intentions. However, Shleifer and Vishny (1988) argued that, "In sum, internal control devices are not especially effective in forcing managers to abstain from non-value-maximizing conduct. In these circumstances, it is not surprising that external means of coercion such as hostile takeovers can come to play a role."

Thus, I argue that the missing "deciphering key" to interpreting when accounting accruals are used opportunistically or efficiently by managers, and even to shedding light on Healy's (1996) unanswered question of "which types of accruals are used for earnings management and which are not," is the governance structures of the firm. One potential measurement of the "external-based" governance that is in the spirit of Shleifer and Vishny (1988) is the G-Index in GIM (2003), since it signals entrenchment via anti-takeover protections against managerial turnover. Put in another way, variation in the G-Index is correlated with the quality of mechanisms (i.e. the external market discipline imposed on managers from potential hostile takeovers) that specifically affect earnings management opportunities or incentives.

Unsurprisingly, this is hardly a "new" idea. Dechow et al. (1996) provide evidence on the corporate governance structures most commonly associated with the earnings manipulations. Given an incentive to manipulate, they find that having a weak governance structure is more likely to lead to the firm actively engaging in earnings management. Specifically, they document that firms subject to SEC enforcement actions are less likely to have an audit committee, more likely to have an insiderdominated board, more likely to have a CEO who is a company founder, and more likely to have a CEO who is chairman of the board. Prior literature had also investigated the association between accounting discretion and governance, and interpreted a negative association as evidence of managerial opportunism (Becker et al., 1998; Gaver, Gaver, and Austin, 1995; Chen and Lee 1995; Guidry, Leone, and Rock, 1999; Healy, 1999; Frankel, Johnson, and Nelson, 2002; Klein, 2002; Menon and Williams, 2004; Peasnell et al., 2005). García, García, and Penalva (2009) find a positive association between commonly used governance proxies for effective monitoring and timely loss recognition. However, none of these studies shows that (less) excess accounting discretion has (positive) negative consequences for shareholders' wealth, or even the possibility that excess discretion can have positive shareholders' wealth effects.

In one of the early important studies by Christie and Zimmerman (1994), they assume that the takeover market would discipline opportunism and use this to identify a sample of firms that is likely to be opportunistic. They do not find evidence of accounting opportunism, thus discounting the Opportunistic Hypothesis and leaning towards efficiency explanations. In a recent important update of the efficiency view using an interesting research methodology, Bowen et al. (2008) find that managers do not systematically exploit poor governance to use accounting discretion for opportunistic purposes; in fact, in accordance with efficient contracting motivations, they use accounting discretion to increase 
shareholder wealth.. Their conclusion was based upon their interpretation of the evidence, uncovered in a two-stage regression model, of a positive association between predicted excess accounting discretion due to governance (or the portion of accruals associated with poor governance in the firststage regression). It also was based on subsequent performance as measured by future cash flow from operation and return on assets, in contrast to the findings in prior literature. In other words, greater accounting discretion is not associated with poor firm performance. Thus, the study by Bowen et al. (2008) was the first to go a step further to document the consequences of excess accounting discretion that is due to poor governance on subsequent firm operating performance.

I argue that these studies, whether in favor of the Opportunistic or Performance Management (or Efficient Contracting) story, have two limitations. Firstly, with the exception of the recent paper by Garcia et al. (2009), most, if not all, of the studies in the past had concentrated on or were seduced by the "dark side" of the governance; that is, the association between accounting discretion and poor governance (and its consequences on subsequent firm performance as examined in Bowen et al., 2008). It missed out on exploring the "light side," that is, the discretionary actions undertaken by the efficient managers when connected to the good governance mechanism, and the consequent implications for the shareholders' wealth. Secondly, and surprisingly, none of the studies thus far has investigated the possibility of how accounting accruals discretion and governance can interactively combine to become a more informative unique signal, beyond what each signal can reveal individually, to impact shareholders' wealth. This latter point will be elaborated upon in the next paragraphs to lead to the main hypotheses of the paper. An interpretation and conclusion on whether there is managerial opportunism or efficiency from accounting discretion will be incomplete and premature without addressing these two concerns.

Financial accounting information is an output produced by management. This suggests that the presence and input of good governance structures, which mitigate agency costs, and are in the influential paper by GIM (2003), are shown to be important in determining firm value. They are necessary to ensure that the accounting information supplied by management is not opportunistically manipulated in response to a variety of incentives. Signals produced by management can therefore be reliably assessed by external parties. The output of earnings quality (EQ), in turn, serves as an input to better governance structures and corporate control mechanisms to improve the productivity of investments through three channels: one, by increasing the efficiency with which the assets in place are managed (governance channel); two, by reducing the error with which managers identify good versus bad investments (project identification); and three, by reducing the information asymmetries among investors and the expropriation of investors' wealth (adverse selection) (Bushman and Smith, 2001; Sloan, 2001). Bushman et al. (2004) also document an inverse association between measures of the informativeness of accounting numbers and governance. In particular, they posit that firms that produce accounting information of limited transparency place a higher burden in governance structures to overcome this shortcoming.

Thus, it is clear that corporate governance and financial accounting are inexorably linked through a complementarity relationship. Complementarity, as pointed out by Ball, Jayaraman and Shivakumar (2010), implies that "financial reporting usefulness depends on its contribution to the total information environment, whereas substitutability implies that usefulness depends on the new information it releases on a stand-alone basis." Thus, both governance and accruals information are jointly informative; each may contain information not contained in the other about the future prospects of the 
firm. Importantly, this suggests the possibility of two previously unexamined relationships that will be developed into three main hypotheses:

Firstly, I posit that governance could be overrated without Low $A A$ as an input. The results in GIM (2003) indicate that the hedge portfolio of buying firms with strong governance (Democracy), and selling firms with weak governance (Dictatorship), can generate significant long-term abnormal return of $8.5 \%$ per year over the sample period from September 1990 to December 1999. The hedge returns are asymmetrically positioned, with 3.5 (5.0)\% from the long (short) position of the Democracy (Dictatorship) firms. In particular, I argue that it is possible that the good governance associated with future positive abnormal stock returns could be attenuated when the subset of Democracy firms with Low AA is removed. Thus, good governance per se does not lead to future positive abnormal returns, contrary to the findings in GIM (2003). In other words, good governance on a stand-alone basis no longer pays off. Isolating the Democracy firms with Low AA should also enhance significantly the governance effects on future positive abnormal returns. Moreover, the positive abnormal returns for the Democracy-Low AA firms should be significantly larger than those of the unconditional Low AA (Democracy) firms, which would indicate an incremental value in the governance (Low AA) signal, lending further weight to the intuition that corporate governance and abnormal accruals are inexorably linked through a complementarity relationship. In addition, mixed governance (termed Drifter) and Dictatorship firms with Low AA should have positive abnormal returns. Thus, Hypothesis 1, stated in its alternative form, is as follow:

Hla: Good governance (Democracy) without being accompanied by Low AA is not associated with positive abnormal returns.

H1b: Democracy accompanied by Low AA is associated with highly significant positive abnormal returns.

H1c: Democracy accompanied by Low AA has larger positive abnormal returns as compared to the unconditional Low AA (Democracy) firms, highlighting the incremental value in the good governance (Low AA) signal; corporate governance and abnormal accruals are inexorably linked through a complementarity relationship.

H1d: Mixed governance (Drifter) and poor governance (Dictatorship) accompanied by Low AA are associated with positive abnormal returns.

Of great interest and debate in the literature is the question of whether investors are able to "see through" transitory distortions in accrual accounting numbers. The explanation by Sloan is that investors are thought to be overly-fixated on earnings (the Earnings-Fixation Hypothesis). It misinterprets the transitory nature of the accruals information, only to be systematically surprised when accruals turn out, in the future, to be less persistent than cashflows. Consequently, abnormal stock returns result as corrections to the initial overreaction in the year immediately following extreme accruals. Thus, Sloan views future reversals to be a result of aggressive or "bad" accounting that originally inflates accruals. Accordingly, a hedge portfolio that buys (sells) firms with low (high) accruals can generate abnormal returns of $10.4 \%$, with 4.9 (5.5)\% from the long (short) position in the subsequent year. Further evidence by Xie (2001), DeFond and Park (2001) and Chan, Chan, Jegadeesh, and Lakonishok (2006) indicate that this "accruals anomaly" is related to abnormal (sometimes called discretionary), 
accruals. ${ }^{(3)}$ They argue that certain discretionary actions on the part of managers induce a transitory element to accruals, with a stronger mean-reverting tendency of discretionary accruals, defined using the Dechow, Sloan and Sweeney (1996) modified Jones model, leading to an overpricing of aggregate accruals.

However, a limitation of Sloan's study is that the returns predictability could be attributed to unidentified risk factors that are correlated with accruals or unknown research design flaws (Kothari, 2001). Healy (1996) pointed out that one major deficiency is the inability of these accruals models to "adequately incorporate the effect of changes in business fundamentals." Healy added that since the residual accruals estimated by the accruals models could arise due to changes in business fundamentals and because of ex post management forecast errors. Thus the models are accrual expectations models rather than models of discretionary accruals, and therefore he would change the label from "discretionary" to "abnormal" if he were to rewrite his influential paper (1985) about the opportunistic behavior of managers. Healy and Whalen (1999) also highlighted their inadequacy to "further identify and explain which types of accruals are used for earnings management and which are not."

Therefore, and secondly, I argue that the conventional interpretation of EQ, measured by the magnitude of abnormal accruals, could vary across governance structures. The noise and uncertainty associated with the abnormal accruals signal - that is, managerial discretion could be interpreted as either opportunistic or conveying credible private signals about firm performance - is interactively resolved with information about the firm's governance structure, and the unique pairing of the signals contains unique information about the future prospects of the firm. Abnormal accruals, when accompanied by good governance, become more informative and the interactive combined signal corroborates the Performance Management Hypothesis. In particular, firms with high or extreme income-increasing AA, usually interpreted as engaging in earnings management, will not have a negative future abnormal return if they happen to be also Democracy firms, contrary to the predictions in Sloan (1996). Firms with high or extreme income-increasing AA, when accompanied by Dictatorship and Drifter governance structures, have negative future stock returns, consistent with Sloan's predictions. Thus, Hypothesis 2, stated in its alternative form, is as follow:

H2a: High AA accompanied by good governance (Democracy) is associated with positive future abnormal return.

H2b: Low AA accompanied by mixed governance (Drifter) or poor governance (Dictatorship) is associated with negative future abnormal return.

\begin{tabular}{llll}
\hline & Low AA & Mixed AA & High AA \\
\hline Democracy & ++ & $?$ & + \\
Drifter & + & $?$ & - \\
Dictatorship & + & $?$ & - \\
\hline
\end{tabular}

Thus, the predicted associations from the two hypotheses are summarized in the above diagram for ease of reference in subsequent discussion and analyses. The signs in the table denote the direction 
of the association with future abnormal return; while the number of signs indicates the magnitude and significance of the abnormal return, where two positive (negative) signs denote highly positive (negative) future returns. I make no predictions on the direction of the associations for the firms with mixed AA.

The evidence from $\mathrm{H} 2$ if rejected in its null form will be strengthened in an additional test if there is evidence as follows: when the portfolio of firms with a revelation of high or extreme income-increasing accruals in period $t$ experiences the biggest magnitude in accruals reversal in period $t+1$, those who are also Democracy firms will have positive future abnormal return, not negative return as was predicted under Sloan's hypothesis. The trend of reported earnings and the subsequent accruals reversals at these firms are interpreted as credible private signals of firm performance by the managers, resulting in larger positive future stock returns, as it has been shown that earnings trend consistency is valued at a premium by the market (Barth, Elliott, and Finn, 1999), as is consistency in benchmark performance (Bartov et al., 2002; Kasznik and McNichols, 2002; Koonce and Lipe, 2010). Thus, Hypothesis 3 , stated in its alternative form, is as follow:

H3: Good governance (Democracy) firms with revelation of high or extreme income-increasing abnormal accruals in period that experience the biggest magnitude in accruals reversal in period $t+1$ are associated with positive future abnormal return.

Recently, and increasingly, the results in GIM (2003) are being challenged as artifacts of either asset pricing model misspecification or unexpected industry performance. The excess returns were not significantly different from zero after controlling for industry clustering effects (Johnson, Moorman, and Sorescu, 2009). Core, Guay, and Rusticus (2006) find that neither analysts nor investors were surprised by differences in operating performance across Democracy or Dictatorship firms; thus they resolve the puzzle of apparent nonzero long-term abnormal return in the absence of firm-specific surprises. Core et al. (2006) also showed that the relative performance of good and bad governance portfolios reverses following the GIM sample period with the good governance portfolio underperforming the bad governance portfolio over the period 2000-2003. Bebchuk, Cohen and Wang (2010) showed that the abnormal return associated with the G-Index during the post-GIM period of 2000-2008 had disappeared. Bebchuk et al. (2010) argued that this result could be due to market participants' learning to appreciate the difference between firms scoring well and poorly on the governance indices after the publication of the results in GIM. Cremers and Nair (2005) examined how the simultaneous consideration of two different governance mechanisms - takeover vulnerability and shareholder activism - is crucial for the documented abnormal return in GIM (2003); they found that the portfolio that buys Democracy firms and shorts Dictatorship firms generates abnormal return only when public pension fund (blockholder) ownership is high as well. In addition, prominent commercial governance ratings are found to have limited or no success in predicting firm performance, restatements, security litigation and other outcomes of interest to shareholders (Daines, Gow, and Larcker, 2010). Until GIM (2003), literature on individual governance characteristics had not identified a conclusive systematic relation to firm performance, and these recent observations reflect the extreme difficulty in distilling all of the complex governance mechanisms into a single, integrated, yet informative overall score, with econometrics issues of governance as an endogenous firm choice, with correlated omitted variables and measurement errors complicating the relationship (Larcker, Richardson, and Tuna, 2007; Larcker and Rusticus, 2010). 
This paper is the first, to the best of my knowledge, to attempt to empirically resolve this long-standing tense debate regarding the relationship between governance and firm performance, and show that both the supporters and the sceptics of the results in GIM (2003) are not incorrect in pointing out that this "performance gap" in governance can be closed by extending the analysis beyond using corporate governance rating on a stand-alone basis. In particular, by considering the interactive effects of abnormal accruals and governance this analysis would yield a more informative combined private signal about firm value.

The observant reader will notice that there is a striking similarity with both the governance and accruals trading strategy in GIM (2003) and Sloan (1996). Both of the documented abnormal returns are concentrated on the short side. Without an economically significant positive return to the long position in the Democracy and extreme income-decreasing accruals portfolio, it is possible that the hedge returns no longer exceed transaction costs, especially given the high transaction costs, limits to arbitrage and short-selling constraints associated with taking a short position (Shleifer and Vishny, 1997; Jones and Lamont, 2002; Boehmer et al., 2009). University of Notre Dame professor of finance Tim Loughran commented in the CFA Digest that he is "always suspicious of anomalies that seem to be focused on the short side" (Trammell, 2010: 39). Loughran related how he wanted to short Krispy Kreme, but was told by his broker that it was not possible because "every single share that's available to be shorted has been shorted." In addition, it appears that the predictive returns from employing the accruals strategy is dissipating, as is what Ron Kahn, Barclays Global Investors (BGI), then global head of research, stated in the Financial Times in 1/2009 that "buying companies with high quality earnings and shorting those most dependent on accruals proved a good strategy, until the market figured it out" (Skypala, 2009). Green, Hand, and Soliman (2009) extended the time period five years beyond the 2003 endpoint used by Lev and Nissim (2006) and Mashruwala et al. (2006) and found that abnormal accruals is no longer an effective predictor of future stock returns because the anomalous returns are arbitraged away by hedge fund investors deploying greater capital. This involved an estimated peak dollar investment of almost $\$ 60$ billion in 2007, by exploiting this signal to the point that they are no longer positive. Thus, a firm with Low AA may even have poor future stock performance if too many investors crowd around a similar trading strategy of buying firms with Low AA.

Therefore, this paper also restores the viability of both investment strategies by documenting how the long position in Democracy firms with Low AA - the Super-Performers - generates abnormal annualized return of $10.5 \%$ over 1991-2008, well in excess of possible transaction costs.

\section{DATA, VARIABLE DESCRIPTION, AND RESEARCH METHODOLOGY}

\section{Measure of Governance and Abnormal Stock Returns}

The data for this study is drawn from the eight volumes published by the Investor Responsibility Research Center (IRRC) that have a governance index score (G-Index) and financial and stock price data from CRSP/Compustat Merged database (CCM), and CRSP database respectively. The G-Index is based on 24 IRRC provisions which restrict shareholder rights, and a higher score is viewed as representing poorer governance. The score of the G-Index ranges from 1 to 24, and GIM (2003) classified companies with G-Index less than or equal to 5 as the 'Democracy' portfolio, while those with a score of 14 and above are classified as the 'Dictatorship' portfolio. The volumes were published on the following dates: September 1990, July 1993, July 1995, February 1998, November 
1999, February 2002, January 2004, and January 2006. The data in the 2008 RiskMetrics governance volume was not used because it is not comparable with data in the earlier IRRC volumes. ${ }^{(4)}$ Following GIM (2003) and subsequent literature, I exclude dual-class firms because of the unique governance structures and regulations prevailing for these sets of firms. Following this, the number of firms (at each publication date) is as follows: 1,303 (1990), 1,303 (1993), 1,333 (1995), 1,642 (1998), 1,492 (2000), 1,588 (2002), 1,675 (2004), 1,619 (2006). An annual time series of the G-Index is constructed using the forward-fill method of GIM (2003) by assuming that the governance provisions remain unchanged from the current date of volume until the current date of the next volume. Given the relative stability of G-Index over time, GIM (2003) argues that any measurement noise using the forward-fill method is likely to be relatively minor. Data in the last IRRC volume of 2006 is filled to the end of 2008. Thus, the sample period in this study is from September 1991 to December 2008. Each firm's G-index is matched with its monthly returns (including dividends) from CRSP, and a value-weighted portfolio is constructed. Portfolios are rebalanced at the beginning of each month and governance data is updated whenever information in a new IRRC volume becomes available.

Abnormal stock returns are captured by the estimated intercept, "alpha," using a Fama-French (1993) three-factor model and includes the Carhart (1997) momentum factor UMD calculated from WRDS. ${ }^{(5)}$ For each calendar month, the value-weighted average return to portfolios of firms grouped into deciles of portfolios sorted by the G-Index is calculated, according to the most recent value of the G-Index. The excess monthly returns are regressed on the four factors as mentioned:

$R_{\mathrm{t}}=\alpha+\beta_{1} R M R F_{\mathrm{t}}+\beta_{2} S M B_{\mathrm{t}}+\beta_{3} H M L_{\mathrm{t}}+\beta_{4} U M D_{\mathrm{t}}+\varepsilon_{\mathrm{t}}$

where $R_{\mathrm{t}}$ is the return of the governance portfolio in excess of the risk-free rate (one-month Treasury bill) in month $t$, or $\left(R_{\mathrm{i}}-R f\right)_{\mathrm{t}}$; $R M R F_{\mathrm{t}}$ is the month $t$ value-weighted market return minus the riskfree rate, and the terms $S M B_{\mathrm{t}}$ (small minus big), $H M L_{\mathrm{t}}$ (high minus low), and $U M D_{\mathrm{t}}$ are the month $t$ returns on zero-investment factor-mimicking portfolios designed to capture size, book-to-market, and momentum effects, respectively. Thus, the estimated intercept $\alpha$ is the abnormal return in excess of what could have been achieved by passive investments in the factors. ${ }^{(6)}$

Following GIM (2003), I replicate their main results in Table VI using their four-factor calendar time portfolio method with equity returns from September 1991 to December 1999. ${ }^{(7)}$ My results are similar and are not presented. The results in GIM (2003) revealed that the positive monthly alpha for the Democracy portfolio, the group of firms with a G-Index of 5 or less, is a statistically significant $0.29 \%$. The portfolios with G-Index of 6 and 7 also generate a qualitatively similar positive monthly alpha of 0.22 and $0.24 \%$ respectively, albeit statistically insignificant. Given that the original Democracy portfolio comprises only around $9 \%$ of the sample data on average, and that it is highly likely that there will be heightened attention on corporate governance in the post-GIM sample period, I extended the sample size of the Democracy portfolio by including firms with qualitatively similar positive monthly alphas and re-grouping the Democracy portfolio as firms with a G-Index score of 7 or less. Following this, Democracy firms now comprise $27.9 \%$ of the sample on average. Importantly, as one of my key tests is to examine whether isolating Democracy firms with Low Abnormal Accruals (AA) as an input will enhance significantly the governance effects on returns $(H 1 b)$, such a re-classification is biased against my findings. In addition, I wish to show that Drifter and Dictatorship can have a positive abnormal return as well (HIC), and such re-grouping will again be biased against my results. Likewise, the negative monthly alpha for the Dictatorship portfolio, the group of firms with a G-Index 
of 14 and above and comprising 5.5\% of the sample on average in GIM (2003), is a statistically significant $0.42 \%$; those with G-Index of 13 and 12 have a qualitatively similar negative monthly alpha at 0.01 and 0.25 respectively. In the same fashion, I re-classified firms with a G-Index of 12 and above as Dictatorship, now comprising $20.0 \%$ of the sample on average. Firms with a G-Index between 8 and 11 comprise $52.1 \%$ of the sample on average, and they are termed Drifter. GIM (2003); all the subsequent literature on governance made no mention about these Drifter firms even though they are the bulk of the sample size. The properties of the Drifter are deliberately examined to test whether Drifter with Low AA can also enjoy a valuation premium with a positive future abnormal return just like the Democracy firms (HId).

\section{Measures of Earnings Quality}

There is no one measure of earnings quality (EQ), a multi-faceted term, which is universally agreed upon (Dechow, Schrand and Ge, 2009). The EQ measures are selected based on the measures' value relevance - the ability to explain variation in contemporaneous stock returns because value relevance is generally viewed in the literature as a direct estimate of the measure's usefulness in equity investors' decision making (e.g. Collins et al., 1997; Francis and Schipper, 1999; Lev and Zarowin, 1999; Barton, Hansen and Pownall, 2010). Moreover, the FASB considers "relevance" as a primary quality that makes accounting information useful to investors (FASB, 1980; Barth, Beaver and Landsman, 2001; Holthausen and Watts, 2001). Below is a description of the two models of EQ that were considered.

Abnormal accruals in the Dechow and Dichev (2002) model. The use of the Dechow and Dichev (2002) model has become the accepted methodology in accounting to capture discretion (e.g. Francis et al., 2005; Dechow, Ge, and Schrand, 2010). Dechow and Dichev derived working capital accrual quality based on the following firm-level time-series regression. ${ }^{(8)}$

$\Delta W C=\beta_{0}+\beta_{1} C F O_{\mathrm{t}-1}+\beta_{2} C F O_{\mathrm{t}}+\beta_{3} C F O_{\mathrm{t}+1}+\varepsilon_{\mathrm{t}}$

Dechow and Dichev (2002) took the position that mapping earnings more closely to operating cash flows is of higher quality. The residuals from the regression reflect the accruals that are unrelated to cash flow realizations. The magnitude of these residuals is a firm-year measure of accruals quality, where higher value of the residuals denotes lower quality. ${ }^{(9)}$ The underlying assumption is that if a performance measure is closer to the firm's cash flows, then accrual accounting - and therefore managers' judgments and estimates - will have less of an effect on the reported performance measures. The measure attempts to isolate the managed or error component of accruals. Measures that are closer to operating cashflows have greater value relevance. The Dechow and Dichev (2002) model appears to provide better estimates of abnormal accruals than other models, and it has much higher explanatory power than the modified Jones model (and its various extensions) and much lower variability in the error term. Jones et al. (2008) provide evidence indicating the superiority of the Dechow and Dichev (2002) model over competing models. Specifically, they show that this model exhibits the strongest association with the existence and magnitude of fraud and non-fraud restatements, and therefore performs better than other models in estimating abnormal accruals.

The $C F O$ (Compustat item $O A N C F$ ) is derived from the Statement of Cash Flows reported under the Statement of Financial Accounting Standards No. 95 (SFAS No. 95, FASB 1987), given the results in Collins and Hribar (2002) showing that the balance-sheet approach to deriving CFO leads 
to noisy and biased estimates. The change in working capital from year $t-1$ to $t(\Delta W C)$ is computed as $\triangle A R+\Delta$ Inventory $-\triangle A P-\triangle T P+\Delta$ Other Assets (net), where $A R$ is accounts receivables, $A P$ is accounts payable, and $T P$ is taxes payable. Specifically, $\triangle W C$ is calculated from Compustat items as $\triangle W C=-(R E C C H+I N V C H+A P A L C H+T X A C H+A O L O C H)$. All variables are scaled by average total assets. Following Dechow and Dichev (2002), I replicate their main findings in Tables 3 and 4 using data from their sample period of 1987-1999. My results are very similar and are not presented.

Ten decile portfolios sorted and ranked by the magnitude of the residuals in the regression model in (2) are formed three months after the end of each fiscal year to ensure that the financial statements are publicly available. ${ }^{(10)}$ The portfolio of firm-months with the lowest (highest) value in residuals is given an abnormal accruals (AA) score of 1 (10). Similar to the approach used in sorting the firms into the three categories of governance structures, the group of firms with a score of 3 and below is re-classified as "Low or Income-Decreasing AA"; those with a score between 4 and 7 are classified as "Mixed AA"; and finally, those with a score of 8 and above are classified as "High or IncomeIncreasing AA."

Abnormal accruals in the modified Jones model (1996). In the original Jones (1991) model, total accruals and working capital accruals are explained as a function of sales growth (Compustat item change in REVT), and plant, property and equipment (PPEGT) respectively, and all variables are scaled by lagged total assets. The modified Jones model by Dechow, Sloan and Sweeney (1995) is adjusted for growth in credit sales (Compustat item change in $R E C T$ ), which are frequently manipulated:

$T A C C_{\mathrm{t}}=\alpha+\beta_{1}\left(\Delta R E V T_{\mathrm{t}}-\Delta R E C T_{\mathrm{t}}\right)+\beta_{2} P P E G T_{\mathrm{t}}+\varepsilon_{\mathrm{t}}$

The power of the Jones' model is increased by this modification, yielding a residual that is uncorrelated with expected (i.e. normal) revenue accruals and better reflects revenue manipulation. ${ }^{(11)}$ TACC is computed as change in current assets (Compustat item change in ACT), minus change in current liabilities (Compustat item change in $L C T$ ), minus change in cash (Compustat item change in $\mathrm{CH}$ ), plus change in short-term debt (Compustat item change in $D L C$ ), minus depreciation (Compustat item $D E P N){ }^{(12)}$ The approach used in sorting and ranking the residuals in the modified Jones model in equation (3) and re-classifying the firm-months into the three categories of AA is similar to that as described for the Dechow and Dichev (2002) model in the previous page.

\section{Measures of Accruals Reversal}

Following Allen, Larson, and Sloan (2010), I define accruals reversal (ACCREV $\left.{ }_{\mathrm{t}+1}\right)$ as the difference between accruals in the current period and accruals in the previous period, with the accruals being estimated as either $\triangle W C$ in equation (2) in the Dechow and Dichev (2002) model, or TACC in equation (3) in the modified Jones model. The implicit assumption in this definition is that accruals are expected to reverse within the next year as has been documented empirically in many studies (e.g. Sloan, 1996; Bradshaw et al., 2001). ${ }^{(13)}$ For instance, a negative accruals reversal involves the revelation of high or extreme income-increasing accruals (e.g. boosting inventory accruals) in period $t$-conventionally interpreted as evidence of earnings management or poor EQ - and the reversal into negative accruals (e.g. inventory writedown) in period $t+1$. The magnitude of $A C C R E V_{\mathrm{t}+1}$ is sorted and ranked to form ten decile portfolios three months after the end of each fiscal year, and then matched with the monthly CRSP returns in period $t+1$. Again, a similar approach as described in the earlier sections is used to re- 
classify the ten portfolios into three portfolio categories: big net negative accruals reversal (Negative Accruals Reversal), mixed accruals reversal (Mixed Accruals Reversal), and big net positive accruals reversal (Positive Accruals Reversal). I am particularly interested in testing the hypothesis, stated in its alternative form, of whether the abnormal return or monthly alpha in the association between both positive and negative accruals reversal and future stock returns is significantly positive (H3), contrary to the negative returns in Sloan's view.

\section{EMPIRICAL RESULTS}

\section{Summary Statistics}

Before examining the returns on the stocks sorted two-dimensionally by governance and abnormal accruals (AA) to test out the three key hypotheses highlighted in the previous section, I first look at the usual firm characteristics for the unconditional portfolios sorted along the single dimension of either governance or AA. These firm characteristics include: Market cap (in millions), calculated monthly as shares outstanding times the month-end share price; Price is a common proxy for transaction costs as it has been documented in prior literature that low-priced stocks have higher trading costs; Turnover is the monthly number of shares traded relative to the number of shares outstanding; BM or book-tomarket is the book value equity per share relative to the month-end share price; $P E$ or price-earnings ratio is end-of-fiscal-year share price relative to EPS; Div or dividend yield is dividend per share relative to share price; Sales Growth (ROA or return on assets) is income before extraordinary items relative to average total assets; Leverage is total net debt relative to total assets; $R \& D$ is research and expenditure expense relative to sales; Capex 1 is capital expenditure relative to sales; Capex 2 is capital expenditure relative to average total assets; Deferred Revenue is deferred current revenue (Compustat item $D R C$ ) relative to average total assets; and Special Item is special items relative to average total assets.

Characteristics of abnormal accruals portfolio. From Panel A of Table 1, the median size for the firms in the High AA portfolio is bigger with a market cap at $\$ 963$ million, as compared to $\$ 835$ million for firms in the low accruals portfolio.

Firms in the High AA portfolio have a relatively higher share price, slightly higher trading intensity based on turnover, lower book-to-market ratio, quite similar PE ratio, lower dividend yield, higher sales growth, surprisingly relatively higher operating performance as measured by return on asset (ROA), relatively similar debt leverage ratio, lower R\&D investments, higher capex spending, higher deferred revenue, and larger negative special items. There is a slightly higher operating performance in the previous year for High AA, while there is deterioration (improvement) in ROA in the following year for High AA (Low AA). There is no difference in the average governance quality between the two sets of firms as measured by the G-Index..$^{(14)}$

Most of my results are similar to prior literature findings, and also consistent with the popular "growth explanation" for the accruals anomaly with a high accruals firm having higher sales growth and higher investments (capital expenditure). Fairfield et al. (2003) and Zhang (2007) argue that the negative future returns associated with high accruals are due to diminishing returns on investments, since the measurement of accruals is scaled by average total assets, and therefore high accruals could be 
capturing high investments or growth. In their iconic study, Lakonishok, Shleifer and Vishny (1994) argue that investors extrapolate past strong growth information too far into the future, and as a result stock prices tend to reverse for growth firms. Titman, Wei, and Xie (2004) suggest that firms with high capital expenditures tend to be overinvesting, and therefore earn lower future stock returns. Cooper, Gulen, and Schill (2008) document a negative relation between asset growth and returns. Fama and French $(1995,1996)$ suggest that growth firms could be financially distressed and hence investors are compensated with lower expected returns. My results appear to suggest that firms with high abnormal accruals may not be financially distressed since they are relatively bigger in size and have better operating performance. A key difference with prior literature is that I am restricted to stocks with data on a G-Index score, which limits my sample size to around 1,500 firms on average per year over 1991-2008. Caylor (2010) finds that managers use discretion in deferred revenue to avoid negative earnings surprises. Interestingly, the high accruals firms in my sample have higher deferred revenue (5.8\% of average total assets), which could suggest that they are also opportunistically manipulating deferred revenue.

Table 1

Comparison of Firm Characteristics for 1991 to 2008

Table 1 reports the firm characteristics of the three categories of portfolios sorted by (a) abnormal accruals (Panel A) and (b) governance quality (Panel B). G-Index is the governance score from IRRC/Risk Metrics. Abnormal Accrual is calculated from the residual in the Dechow and Dichev (2002) model. The magnitude of the abnormal accrual is sorted into 10-decile portfolios and firms where the lowest (highest) abnormal accrual have an AA Score of 1 (10). Market cap (in millions) is calculated monthly as shares outstanding times the month-end share price. Turnover is the monthly number of shares traded relative to the number of shares outstanding. BM or book-to-market is the book value equity per share relative to the month-end share price. PE or price-earnings ratio is the end-of-fiscal-year share price relative to EPS. Div or dividend yield is dividend per share relative to share price. ROA or return on assets is income before extraordinary items relative to average total assets. Leverage is total net debt relative to total assets. $R \& D$ is research and expenditure expense relative to sales. Capex1 is capital expenditure relative to sales. Capex2 is capital expenditure relative to average total assets. Deferred Revenue is deferred current revenue (Compustat item $D R C$ ) relative to average total assets. Special Item is special items relative to average total assets. $N$ is the number of firm-months. Means tests are based on time-series of monthly cross-sectional means.

Panel A: Firms Sorted by Abnormal Accruals

\begin{tabular}{|c|c|c|c|c|c|c|c|}
\hline & \multicolumn{2}{|c|}{$\begin{array}{c}\text { Low AA } \\
(\mathrm{N}=24139)\end{array}$} & \multicolumn{2}{|c|}{$\begin{array}{c}\text { High AA } \\
(\mathrm{N}=21412)\end{array}$} & \multirow{2}{*}{$\begin{array}{c}\text { Means } \\
\text { t-test } \\
p \text {-value }\end{array}$} & \multicolumn{2}{|c|}{$\begin{array}{c}\text { Mixed EQ } \\
(\mathrm{N}=41936)\end{array}$} \\
\hline & Mean & Median & Mean & Median & & Mean & Median \\
\hline G-Index & 8.8 & 9.0 & 8.8 & 9.0 & 0.897 & 9.1 & 9.0 \\
\hline Abnormal Accrual & -0.031 & -0.022 & 0.029 & 0.022 & $<.01$ & 0.000 & -0.000 \\
\hline Market cap & 4087.811 & 835.380 & 4522.744 & 963.255 & $<.01$ & 5061.764 & 1393.431 \\
\hline Price & 26.012 & 21.750 & 28.171 & 23.938 & $<.01$ & 31.160 & 27.813 \\
\hline Turnover & 1.567 & 1.022 & 1.609 & 0.990 & $<.01$ & 1.258 & 0.786 \\
\hline $\mathrm{BM}$ & 0.580 & 0.451 & 0.512 & 0.411 & $<.01$ & 0.560 & 0.484 \\
\hline PE & 17.354 & 16.618 & 18.179 & 16.252 & 0.535 & 20.603 & 16.046 \\
\hline Div & 0.016 & 0.000 & 0.012 & 0.002 & $<.01$ & 0.024 & 0.013 \\
\hline Sales Growth & 0.070 & 0.047 & 0.172 & 0.109 & $<.01$ & 0.105 & 0.074 \\
\hline $\mathrm{ROA}_{\mathrm{t}-1}$ & 0.023 & 0.041 & 0.030 & 0.054 & $<.01$ & 0.038 & 0.043 \\
\hline $\mathrm{ROA}_{t}$ & 0.011 & 0.033 & 0.061 & 0.069 & $<.01$ & 0.045 & 0.046 \\
\hline $\mathrm{ROA}_{t+1}$ & 0.037 & 0.048 & 0.049 & 0.060 & $<.01$ & 0.048 & 0.048 \\
\hline Leverage & 0.113 & 0.118 & 0.105 & 0.118 & $<.01$ & 0.216 & 0.242 \\
\hline $\mathrm{R} \& \mathrm{D}$ & 0.191 & 0.068 & 0.290 & 0.010 & $<.01$ & 1.164 & 0.000 \\
\hline Capex 1 & 0.073 & 0.038 & 0.095 & 0.045 & $<.01$ & 0.131 & 0.051 \\
\hline Capex2 & 0.055 & 0.041 & 0.066 & 0.051 & $<.01$ & 0.064 & 0.051 \\
\hline Deferred Revenue & 0.010 & 0.000 & 0.058 & 0.000 & $<.01$ & 0.005 & 0.000 \\
\hline Special Item & -0.023 & -0.001 & -0.011 & 0.000 & $<.01$ & -0.009 & 0.000 \\
\hline
\end{tabular}


Panel B: Firms Sorted by Governance Quality

\begin{tabular}{|c|c|c|c|c|c|c|c|}
\hline & \multicolumn{2}{|c|}{$\begin{array}{c}\text { Democracy } \\
(\mathrm{N}=26677)\end{array}$} & \multicolumn{2}{|c|}{$\begin{array}{l}\text { Dictatorship } \\
(\mathrm{N}=15706)\end{array}$} & \multirow{2}{*}{$\begin{array}{c}\text { Means } \\
\underline{\text { t-test }} \\
\text { p-value }\end{array}$} & \multicolumn{2}{|c|}{$\begin{array}{c}\text { Drifter } \\
(\mathrm{N}=45134)\end{array}$} \\
\hline & Mean & Median & Mean & Median & & Mean & Median \\
\hline G-Index & 5.8 & 6.0 & 12.9 & 13.0 & $<.01$ & 9.5 & 9.0 \\
\hline Abnormal Accrual & -0.002 & -0.000 & -0.001 & -0.001 & $<.01$ & -0.001 & -0.000 \\
\hline AA Score & 5.3 & 5.0 & 5.4 & 5.0 & $<.01$ & 5.4 & 5.0 \\
\hline Market cap & 4592.904 & 918.294 & 5024.484 & 1622.911 & $<.01$ & 4575.248 & 1141.564 \\
\hline Price & 26.733 & 23.188 & 32.698 & 29.130 & $<.01$ & 29.070 & 25.420 \\
\hline Turnover & 1.521 & 0.881 & 1.090 & 0.766 & $<.01$ & 1.492 & 0.955 \\
\hline $\mathrm{BM}$ & 0.560 & 0.448 & 0.533 & 0.468 & $<.01$ & 0.557 & 0.460 \\
\hline $\mathrm{PE}$ & 23.093 & 16.300 & 16.843 & 16.208 & $<.01$ & 17.537 & 16.155 \\
\hline Div & 0.016 & 0.000 & 0.028 & 0.018 & $<.01$ & 0.017 & 0.058 \\
\hline Sales Growth & 0.131 & 0.088 & 0.087 & 0.063 & $<.01$ & 0.108 & 0.073 \\
\hline $\mathrm{ROA}_{\mathrm{t}-1}$ & 0.035 & 0.048 & 0.042 & 0.045 & $<.01$ & 0.027 & 0.044 \\
\hline $\mathrm{ROA}_{\mathrm{t}}$ & 0.045 & 0.050 & 0.045 & 0.047 & 0.737 & 0.034 & 0.047 \\
\hline $\mathrm{ROA}_{\mathrm{t}+1}$ & 0.050 & 0.052 & 0.051 & 0.051 & 0.516 & 0.040 & 0.049 \\
\hline Leverage & 0.126 & 0.115 & 0.210 & 0.228 & $<.01$ & 0.163 & 0.186 \\
\hline R\&D & 0.183 & 0.000 & 0.035 & 0.003 & $<.01$ & 1.201 & 0.000 \\
\hline Capex 1 & 0.096 & 0.047 & 0.057 & 0.040 & $<.01$ & 0.129 & 0.047 \\
\hline Capex2 & 0.065 & 0.049 & 0.053 & 0.046 & $<.01$ & 0.063 & 0.048 \\
\hline Deferred Revenue & 0.008 & 0.000 & 0.002 & 0.000 & $<.01$ & 0.007 & 0.000 \\
\hline Special Item & -0.012 & 0.000 & -0.012 & 0.000 & 0.472 & -0.014 & 0.000 \\
\hline
\end{tabular}

Dechow and Ge (2006) find that low accrual firms are more likely to have negative non-cash special items, such as an asset write-off. These low accrual firms with negative special items have higher ROA and higher positive future abnormal returns, and they interpret the results to mean that accounting accruals decisions by managers to take a one-time charge is a signal that it is taking actions to turn the firm around. Also, they infer that investors fail to understand that these negative special items are transitory and exhibit low earnings persistence, and thus, the accruals anomaly is more pronounced for these firms. I find that the Low AA firms in my sample have negative special items (1.1\% of average total assets) and ROA improves in the following year, consistent with Dechow and Ge (2006).

Characteristics of governance quality portfolio. From Panel B of Table 1, the median size for the firms in the Democracy portfolio is surprisingly smaller and has with a market cap at $\$ 918$ million, as compared to $\$ 1.6$ billion in Dictatorship, as it is often thought that bigger firms have more resources to spend on installing corporate governance practices. Democracy firms have a relatively lower share price, higher turnover, quite similar book-to-market ratio, higher PE ratio, lower dividend yield, higher sales growth, less leverage, higher R\&D, higher capex, higher deferred revenue, and relatively similar slight negative special items. Surprisingly, there is no significant difference in the comparison of current and next-period operating performance (ROA) for both sets of firms.

\section{Baseline Results}

Table 2 shows the monthly intercepts or alphas in the Fama-French-Carhart regressions for the portfolios double-sorted independently by governance quality and abnormal accruals (AA) measured using the Dechow and Dichev (2002) model. ${ }^{(15)}$ The intercepts, which indicate abnormal future returns, have been multiplied by 100 so that they can be interpreted as percentages. 
Table 2

\section{Monthly Alphas of Portfolios Sorted Two-dimensionally by Governance and Abnormal Accruals (Dechow and Dichev, 2002)}

Table 2 reports the portfolios' value-weighted monthly alphas, estimated using Fama-French (1993) three-factor model and includes the Carhart (1997) momentum factor from WRDS.

$R_{\mathrm{t}}=\alpha+\beta_{1} R M R F_{\mathrm{t}}+\beta_{2} S M B_{\mathrm{t}}+\beta_{3} H M L_{\mathrm{t}}+\beta_{4} U M D_{\mathrm{t}}+\varepsilon_{\mathrm{t}}$

The dependent variable is the value-weighted monthly portfolio excess return $R_{t}$. The explanatory variables $R M R F, S M B, H M L$ and $U M D$ are the returns to zero-investment portfolios designed to capture market, size, book-to-market, and momentum effects, respectively. The coefficients of these factors are not reported in the table for brevity. Stocks formed in the portfolios are sorted two-dimensionally by governance and abnormal accruals (AA, measured by Dechow and Dichev (2002) model). Stocks sorted by governance are reset in September 1990, July 1993, July 1995, February 1998, February 2000, February 2002, January 2004, and January 2006, which are the months when new data on G-Index are available. I extended the sample size of the Democracy (good governance) portfolio in GIM (2003) by including firms with qualitatively similar positive monthly alphas and re-grouping the Democracy portfolio as firms with a G-Index score of 7 or less. Following this, Democracy firms now comprise $27.9 \%$ of the sample on average as compared to the original 9\%. Similarly, I re-classified firms with a G-Index of 12 and above as Dictatorship (bad governance), now comprising $20.0 \%$ of the sample on average, as compared to the original $5.5 \%$. The remaining mixed governance firms, termed Drifter, have a G-Index between 8 and 11 and comprise $52.1 \%$ of the sample on average. For the stocks sorted by EQ, ten decile portfolios ranked by the magnitude of the residuals in the Dechow and Dichev (2002) model are formed three months after the end of each fiscal year to ensure that the financial statements are publicly available. The portfolio of firms with the lowest (highest) value in residuals is given an AA score of 1 (10). Similar to the approach used in sorting the firms into the three categories of governance structures, the group of firms with a score of 3 and below is re-classified as "Low or Income-Decreasing Abnormal Accruals (AA)"; those with a score between 4 and 7 are classified as "Mixed AA"; and finally, those with a score of 8 and above are classified as "High or Income-Increasing AA". Panel A describes the overall sample period from September 1990 to December 2008; Panel B is the sub-period from September 1, 1991 to December 31, 1999 as in GIM (2003); and Panel C is the post-GIM subperiod from January 1, 2000 to December 31, 2008. All standard errors are White (1980) robust and the t-statistics are reported in parentheses. Levels of significance are indicated by $*, * *, * * *$ for $10 \%, 5 \%$, and $1 \%$ respectively.

Panel A: Overall Sample Period Sep 1, 1991 - Dec 31, 2008

\begin{tabular}{lcccc}
\hline Portfolios & Low AA & Mixed AA & High AA & Overall \\
\hline \multirow{2}{*}{ Democracy } & $0.875^{* * *}$ & -0.079 & 0.268 & 0.289 \\
& $(2.73)$ & $(-0.28)$ & $(0.86)$ & $(1.42)$ \\
Drifter & $0.520^{* *}$ & 0.012 & $-0.626^{* * *}$ & -0.068 \\
& $(2.22)$ & $(0.07)$ & $(-2.90)$ & $(-0.58)$ \\
Dictatorship & 0.197 & -0.075 & -0.076 & 0.019 \\
& $(0.79)$ & $(-0.38)$ & $(-0.26)$ & $(0.12)$ \\
Overall & $0.535^{* * *}$ & -0.034 & -0.187 & $(-1.03)$ \\
\hline
\end{tabular}

Panel B: Sub-period (1) Sep 1, 1991 - Dec 31, 1999

\begin{tabular}{lcccc}
\hline Portfolios & Low AA & Mixed AA & High AA & Overall \\
\hline \multirow{2}{*}{ Democracy } & 0.579 & -0.058 & 0.559 & 0.212 \\
& $(1.35)$ & $(-0.18)$ & $(1.52)$ & $(0.94)$ \\
Drifter & $0.765^{* * *}$ & -0.028 & $-0.686^{* * *}$ & -0.015 \\
& $(2.82)$ & $(-0.17)$ & $(-2.68)$ & $(-0.12)$ \\
Dictatorship & 0.050 & -0.015 & -0.161 & 0.013 \\
& $(0.18)$ & $(-0.06)$ & $(-0.55)$ & $(0.07)$ \\
Overall & $0.546^{* *}$ & -0.052 & -0.025 & \\
\hline
\end{tabular}


Panel C: Sub-period (2) Jan 1, 2000 - Dec 31, 2008

\begin{tabular}{lllll}
\hline Portfolios & Low AA & Mixed AA & High AA & Overall \\
\hline \multirow{2}{*}{ Democracy } & $0.814^{*}$ & 0.259 & -0.144 & 0.399 \\
& $(1.84)$ & $(0.66)$ & $(-0.32)$ & $(1.31)$ \\
\multirow{2}{*}{ Drifter } & 0.325 & 0.123 & -0.533 & -0.017 \\
& $(0.87)$ & $(0.43)$ & $(-1.51)$ & $(-0.09)$ \\
Dictatorship & 0.042 & 0.027 & 0.241 & 0.084 \\
& $(0.11)$ & $(0.09)$ & $(0.57)$ & $(0.34)$ \\
Overall & 0.412 & 0.143 & -0.314 & \\
& $(1.31)$ & $(0.62)$ & $(-1.10)$ & \\
\hline
\end{tabular}

In Panel A of Table 2, which describes the data for the overall sample period from September 1, 1991 to December 31, 2008, the monthly alpha for the unconditional Democracy portfolio is positive at $0.289 \%$, albeit statistically insignificant. For the sub-period September 1, 1991 to December 31, 1999 in Panel B of Table 2, which is the original sample period in GIM (2003), the monthly alpha is positive at $0.212 \%$, which is quite close in economic significance to the $0.2 \%$ for the original and smaller Democracy portfolio in GIM (2003), although it is statistically insignificant. Recall that as per the description in Section 3, I have extended the sample size of the Democracy portfolio, which now comprises $27.9 \%$ of the sample on average, as compared to the original $9 \%$ in GIM (2003). The unconditional Low AA portfolio has a significant positive abnormal future return at $6.4 \%$ per year (t-statistics of 2.60) over 1991-2008 and 6.6\% (t-statistics of 2.16) in the sub-period 1991-1999, although the positive return is no longer significant in the sub-period 2000-2008, which is consistent with Sloan (1996) and also with the recent findings in Green et al. (2008) that the returns to the abnormal accruals portfolio are dissipating due to hedge funds overcrowding the trades in exploiting this signal.

The portfolio of Democracy firms with Low AA, dubbed Super-Performers, generates a positive monthly alpha of $0.875 \%$ (t-statistics of 2.73 ), or abnormal return of $10.5 \%$ per year from 1991 to 2008. Thus, the null in $H 1 b$ can be rejected. The $10.5 \%$ abnormal return for this Super-Performers or Democracy-Low AA portfolio is far larger than the return for the unconditional Democracy portfolio (3.5\%). It can be inferred that the incremental value in the Low AA signal is $7.0 \%$ per year. Notice also how the $10.5 \%$ abnormal return for this Democracy-Low $A A$ portfolio is higher than the return for the unconditional Low AA portfolio (6.6\%); thus, the incremental value in the good governance signal is $3.9 \%$. These results lend further weight to my conjecture that corporate governance and abnormal accruals are inexorably linked through a complementarity relationship; therefore the null in HIc can be rejected. The abnormal return of these Super-Performers is also economically larger (700 basis points per year) than the long position documented in GIM (2003), and is also 200 basis points more than the entire hedge returns in GIM (2003). Interestingly, a closer investigation indicates that some of these Super-Performers include well-known, institutional big-cap stocks, such as Coca-Cola Co, AT\&T, Hewlett-Packard, Wyeth, Lowe's, Home Depot, and EMC, formed in the portfolio at various months in the sample period. 
In addition, I find evidence that removing these Super-Performers will reduce the remaining Democracy portfolio returns to no different from zero statistically over the period of 1991-2008, and over the subperiod of 1991-1999 that was examined in GIM (2003) (H1a). In other words, good governance per se no longer pays off, contrary to the findings in GIM (2003). Therefore, the null in Hla can be rejected.

Mixed governance firms, with a G-Index between 8 and 11, comprise $52.1 \%$ of the sample on average, and they are termed Drifter. GIM (2003) and all of the subsequent literature on governance made no mention about these Drifter firms even though they are the bulk of the sample size. The unconditional monthly alpha for Drifter portfolio is negative on average in 1991-2008 and in the two sub-periods (1991-1999 and 2000-2008). Interestingly, I find that the portfolio of Drifter with Low AA has a significantly positive monthly alpha of $0.520 \%$ (t-statistics of 2.22), or abnormal return of $6.2 \%$ per year over 1991-2008; the returns are even greater during the sub-period 1991-1999 at 9.2\% per year (t-statistics of 2.82). Thus, it is not only good governance firms that enjoy positive future abnormal return; Drifter with Low AA can revel in this capital appreciation outperformance as well. The factor loading for $S M B$ is significantly positive, indicating that the stocks in this particular Drifter-High $E Q$ portfolio tend to be smaller stocks, although this no longer holds true in the sub-period 1991-99. During the sub-period of 2000-2008, the monthly alpha for the Drifter-High EQ portfolio dropped to an insignificant $0.325 \%$. Surprisingly, even Dictatorship with Low AA can have positive abnormal return at $2.4 \%$ per year over 1991-2008, albeit statistically insignificant, as compared to $0.2 \%$ per year for the unconditional Dictatorship portfolio. The null in Hld can thus be rejected.

For the unconditional High AA portfolio, the abnormal future returns is negative $2.2 \%$ per year over 1991-2008, as expected under Sloan (1996), albeit statistically insignificant. Democracy with High AA have a positive, albeit insignificant, annualized abnormal return of $3.2 \%$, which lends some support for the null rejection in $H 2 a$. Unsurprisingly, High AA firms accompanied by Dictatorship and Drifter governance structures have negative abnormal annualized returns of 0.9 and $7.5 \%$ (t-statistics of -2.90) respectively, which are as predicted by Sloan (1996); thus, the null in $H 2 b$ can be rejected, particularly for the Drifter-High AA portfolio. Interestingly, the excess performance for the DrifterHigh AA portfolio is larger (by 200 basis points per year) than the returns from the short position (5.5\% per year) documented in Sloan (1996). The factor loading SMB for the Drifter-High AA firms is significantly positive, indicating that the stocks in this portfolio tend to be smaller stocks.

The small negative insignificant returns for the short position of the Dictatorship-High AA portfolio may seem, at first blush, surprising since it is the worst of both worlds. However, this is consistent with the findings in Core et al. (2006) who find that weak governance firms have poorer operating performance, but investors and analysts continue to forecast this difference and hence are not systematically surprised to the extent that leads to stock price declines. The results are also consistent with Bowen, Rajgopal and Venkatachalam (2008) who find that managers do not systematically exploit poor governance structures to engage in accounting discretionary at the shareholders' expense since the subsequent future operating performance is positive. A caveat is that stock returns as a yardstick of performance measurement is a "noisy" measure, since bad governance can impose substantial ongoing costs on shareholders with no return effect so long as shareholders are not surprised by the costs. 
Table 3

\section{Accruals Reversal (Dechow and Dichev, 2002) and Future Stock Returns}

Table 3 reports the portfolios' value-weighted monthly alphas, estimated using the Fama-French (1993) three-factor model and includes the Carhart (1997) momentum factor from WRDS.

$R_{\mathrm{t}}=\alpha+\beta_{1} R M R F_{\mathrm{t}}+\beta_{2} S M B_{\mathrm{t}}+\beta_{3} H M L_{\mathrm{t}}+\beta_{4} U M D_{\mathrm{t}}+\varepsilon_{\mathrm{t}}$

The dependent variable is the value-weighted monthly portfolio excess return $R_{\mathrm{t}}$. The explanatory variables $R M R F, S M B, H M L$ and $U M D$ are the returns to zero-investment portfolios designed to capture market, size, book-to-market, and momentum effects, respectively. The coefficients of these factors are not reported in the table for brevity. The portfolios are sorted two-dimensionally by governance and accruals reversal $A C C R E V_{\mathrm{t}+1}$ (measured as the difference between accruals in the current period and accruals in the previous period, with the accruals being estimated as $\Delta W C$ in equation (2) in Dechow and Dichev (2002) model) that were described in Section 3. The stocks sorted by governance are reset in September 1990, July 1993, July 1995, February 1998, February 2000, February 2002, January 2004, and January 2006, which are the months when new data on G-Index are available. I extended the sample size of the Democracy (good governance) portfolio in GIM (2003) by including firms with qualitatively similar positive monthly alphas and re-grouping the Democracy portfolio as firms with a G-Index score of 7 or less. Following this, Democracy firms now comprise $27.9 \%$ of the sample on average as compared to the original $9 \%$. Similarly, I re-classified firms with a G-Index of 12 and above as Dictatorship (bad governance), now comprising 20.0\% of the sample on average, as compared to the original 5.5\%. The remaining mixed governance firms, termed Drifter, have a G-Index between 8 and 11 and comprise $52.1 \%$ of the sample on average. The magnitude of $A C C R E V_{t+1}$ is sorted and ranked to form ten decile portfolios three months after the end of each fiscal year to ensure that the financial statements are publicly available, and then they are matched with the monthly CRSP returns in period $t+1$. The portfolio of firms with the lowest (highest) value in ACCREV $V_{t+1}$ is given an accruals reversal score of 1 (10). The group of firms with a score of 3 and below is re-classified as big net negative accruals reversal (Negative Accruals Reversal); those with a score between 4 and 7 are classified as mixed accruals reversal (Mixed Accruals Reversal); and finally, those with a score of 8 and above are classified as big net positive accruals reversal (Positive Accruals Reversal). Panel A describes the overall sample period from September 1990 to December 2008; Panel B is the sub-period from September 1, 1991 to December 31, 1999 as in GIM (2003); and Panel C is the post-GIM sub-period from January 1, 2000 to December 31, 2008. All standard errors are White (1980) robust and the t-statistics are reported in parentheses. Levels of significance are indicated by *,**, *** for $10 \%, 5 \%$, and $1 \%$ respectively.

Panel A: Overall Sample Period Sep 1, 1991 - Dec 31, 2008

\begin{tabular}{lcccc}
\hline Portfolios & $\begin{array}{c}\text { Positive } \\
\text { ACCREV }\end{array}$ & $\begin{array}{c}\text { Mixed } \\
\text { ACCREV }\end{array}$ & $\begin{array}{c}\text { Negative } \\
\text { ACCREV }\end{array}$ & Overall \\
\hline \multirow{2}{*}{ Democracy } & 0.197 & 0.050 & $0.897^{* *}$ & 0.289 \\
\multirow{2}{*}{ Drifter } & $(0.57)$ & $(0.24)$ & $(1.98)$ & $(1.42)$ \\
& -0.198 & -0.006 & -0.060 & -0.068 \\
Dictatorship & $(-0.84)$ & $(-0.04)$ & $(-0.24)$ & $(-0.58)$ \\
& 0.106 & 0.033 & -0.026 & $(-0.09)$ \\
Overall & $(0.38)$ & $(0.19)$ & 0.153 & $(0.09)$ \\
& 0.110 & -0.051 & $(0.68)$ & \\
\hline
\end{tabular}

Panel B: Sub-period (1) Sep 1, 1991 - Dec 31, 1999

\begin{tabular}{|c|c|c|c|c|}
\hline Portfolios & $\begin{array}{c}\text { Positive } \\
\text { ACCREV }\end{array}$ & $\begin{array}{c}\text { Mixed } \\
\text { ACCREV }\end{array}$ & $\begin{array}{c}\text { Negative } \\
\text { ACCREV }\end{array}$ & Overall \\
\hline Democracy & $0.807 * *$ & 0.007 & 0.515 & 0.212 \\
\hline Democracy & $\begin{array}{l}(2.30) \\
-0.367\end{array}$ & $\begin{array}{l}(0.02) \\
0.126\end{array}$ & $\begin{array}{c}(1.13) \\
-0.046\end{array}$ & $\begin{array}{c}(0.94) \\
-0.015\end{array}$ \\
\hline Drifter & $(-1.38)$ & (0.93) & $(-0.16)$ & $(-0.12)$ \\
\hline Dictatorship & $\begin{array}{l}-0.150 \\
(-0.34)\end{array}$ & $\begin{array}{l}0.099 \\
(0.45\end{array}$ & $\begin{array}{l}0.201 \\
(0.56)\end{array}$ & $\begin{array}{l}0.189 \\
(0.12)\end{array}$ \\
\hline Overall & $\begin{array}{l}0.247 \\
(1.30)\end{array}$ & $\begin{array}{l}0.069 \\
(0.57)\end{array}$ & $\begin{array}{l}0.028 \\
(0.12)\end{array}$ & \\
\hline
\end{tabular}


Panel C: Sub-period (2) Jan 1, 2000 - Dec 31, 2008

\begin{tabular}{lcccc}
\hline Portfolios & $\begin{array}{c}\text { Positive } \\
\text { ACCREV }\end{array}$ & $\begin{array}{c}\text { Mixed } \\
\text { ACCREV }\end{array}$ & $\begin{array}{c}\text { Negative } \\
\text { ACCREV }\end{array}$ & Overall \\
\hline \multirow{2}{*}{ Democracy } & -0.059 & -0.099 & $1.344^{* * *}$ & 0.399 \\
& $(-0.11)$ & $(-0.34)$ & $(1.98)$ & $(1.31)$ \\
Drifter & 0.021 & -0.038 & 0.102 & -0.017 \\
& $(0.06)$ & $(-0.16)$ & $(0.27)$ & $(-0.09)$ \\
Dictatorship & 0.396 & 0.102 & -0.095 & 0.013 \\
& $(1.09)$ & $(0.38)$ & $(-0.22)$ & $(0.07)$ \\
Overall & 0.061 & -0.052 & 0.384 & \\
& $(0.18)$ & $(-0.26)$ & $(1.09)$ & \\
\hline
\end{tabular}

In the additional test for the Negative ACCREV portfolio of stocks with a revelation of high or extreme income-increasing accruals in period $t$ which experiences the greatest magnitude in accruals reversal in period $t+1$, the results in Table 3 indicate positive annualized abnormal future returns of $10.8 \%$ (t-statistics of 1.98) per year for those are also Democracy firms, contrary to the expectation of negative future returns in Sloan (1996). ${ }^{(16)}$ Delving deeper into this Negative ACCREV-Democracy portfolio, I find that $43 \%$ of the sample are Democracy-High AA in the previous period. This means that not all the firms with extreme high abnormal accruals in period $t$ reverse sharply in period $t+1$. For this specific group $(\mathrm{N}=2785)$, the future positive abnormal returns is even larger at $20.3 \%$ per year over 1991-2008 (t-statistics of 3.18)! $!^{(17)}$ Again, this is not the negative return that was expected under Sloan's hypothesis. On the one hand, negative accruals reversal may imply aggressive accounting, such as managers opportunistically boosting inventory accruals in period $t$ and subsequently being forced to write down inventory in period $t+1$ when demand falls short. On the other hand, as the cash consequences that the accruals anticipate are realized when the accruals reverse, the trend of reported earnings and the subsequent accruals reversals at these negative accruals reversal firms who have at the same time good governance structures are interpreted as credible private signals of firm performance by the managers, resulting in larger positive future stock return. This can be explained by how earnings trend consistency is valued at a premium by the market (Barth, Elliott, and Finn, 1999), as is consistency in benchmark performance (Bartov et al., 2002; Kasznik and McNichols, 2002). Thus, the null in $H 3$ can be rejected.

It may be argued that if there is an incremental value in the good governance signal, then there should be a positive abnormal future return for the Positive ACCREV-Democracy portfolio as well, or those firms who have low or extreme income-decreasing accruals in period $t$ which experiences large accruals reversal to high accruals in period $t+1$. I find some evidence that this holds true, particularly in the sub-period 1991-1999 where the Positive ACCREV-Democracy portfolio generates positive abnormal future return of $9.7 \%$ per year, although the magnitude is greatly reduced to $2.4 \%$ for the overall sample period 1991-2008 and is also no longer significant. The factor loadings for SMB and $H M L$ are significantly positive and negative respectively, indicating that the stocks in this particular portfolio tend to be smaller and "growth" stocks.

Overall, the empirical results from testing the three hypotheses highlight the joint importance of governance and abnormal accruals in contributing to the total information environment that separates winners from losers. 
Table 4

\section{Monthly Alphas of Portfolios Sorted Two-dimensionally by Governance and Abnormal Accruals (Dechow et al, 1996)}

Table 4 reports the portfolios' value-weighted monthly alphas, estimated using the Fama-French (1993) three-factor model and includes the Carhart (1997) momentum factor from WRDS.

$R_{\mathrm{t}}=\alpha+\beta_{1} R M R F_{\mathrm{t}}+\beta_{2} S M B_{\mathrm{t}}+\beta_{3} H M L_{\mathrm{t}}+\beta_{4} U M D_{\mathrm{t}}+\varepsilon_{\mathrm{t}}$

The dependent variable is the value-weighted monthly portfolio excess return $R_{t}$. The explanatory variables $R M R F, S M B, H M L$ and $U M D$ are the returns to zero-investment portfolios designed to capture market, size, book-to-market, and momentum effects, respectively. The coefficients of these factors are not reported in the table for brevity. Stocks formed in the portfolios are sorted twodimensionally by governance and abnormal accruals (AA, measured by Dechow et al (1996) model). Stocks sorted by governance are reset in September 1990, July 1993, July 1995, February 1998, February 2000, February 2002, January 2004, and January 2006, which are the months when new data on G-Index are available. I extended the sample size of the Democracy (good governance) portfolio in GIM (2003) by including firms with qualitatively similar positive monthly alphas and re-grouping the Democracy portfolio as firms with a G-Index score of 7 or less. Following this, Democracy firms now comprise $27.9 \%$ of the sample on average as compared to the original 9\%. Similarly, I re-classified firms with a G-Index of 12 and above as Dictatorship (bad governance), now comprising $20.0 \%$ of the sample on average, as compared to the original 5.5\%. The remaining mixed governance firms, termed Drifter, have a G-Index between 8 and 11 and comprise $52.1 \%$ of the sample on average. For the stocks sorted by EQ, ten decile portfolios ranked by the magnitude of the residuals in the Dechow and Dichev (2002) model are formed three months after the end of each fiscal year to ensure that the financial statements are publicly available. The portfolio of firms with the lowest (highest) value in residuals is given an AA score of 1 (10). Similar to the approach used in sorting the firms into the three categories of governance structures, the group of firms with a score of 3 and below is re-classified as "Low or Income-Decreasing Abnormal Accruals (AA)"; those with a score between 4 and 7 are classified as "Mixed AA"; and finally, those with a score of 8 and above are classified as "High or Income-Increasing AA". Panel A describes the overall sample period from September 1990 to December 2008; Panel B is the sub-period from September 1, 1991 to December 31, 1999 as in GIM (2003); and Panel C is the post-GIM sub-period from January 1, 2000 December 31, 2008. All standard errors are White (1980) robust and the t-statistics are reported in parentheses. Levels of significance are indicated by *, **, $* * *$ for $10 \%, 5 \%$, and $1 \%$ respectively.

Panel A: Overall Sample Period Sep 1, 1991 - Dec 31, 2008

\begin{tabular}{lcccc}
\hline Portfolios & Low AA & Mixed AA & High AA & Overall \\
\hline \multirow{2}{*}{ Democracy } & 0.391 & 0.149 & -0.054 & 0.139 \\
& $(1.55)$ & $(0.93)$ & $(-0.24)$ & $-1.11)$ \\
Drifter & 0.274 & 0.183 & $(-1.21)$ & 0.090 \\
& $(1.35)$ & $(1.41)$ & 0.191 & $(0.92)$ \\
Dictatorship & 0.328 & 0.079 & $(0.91)$ & $(1.13)$ \\
& $(1.55)$ & $(0.65)$ & -0.065 & $(-0.46)$ \\
Overall & $0.318^{* *}$ & 0.142 & & \\
\hline
\end{tabular}

Panel B: Sub-period (1) Sep 1, 1991 - Dec 31, 1999

\begin{tabular}{lcccc}
\hline Portfolios & Low AA & Mixed AA & High AA & Overall \\
\hline \multirow{2}{*}{ Democracy } & $0.737^{* *}$ & 0.190 & 0.069 & $0.307^{* *}$ \\
& $(2.16)$ & $(0.92)$ & $(0.22)$ & $(1.94)$ \\
Drifter & $0.706^{* *}$ & 0.098 & -0.147 & 0.210 \\
& $(2.49)$ & $(0.64)$ & $(-0.52)$ & $(1.58)$ \\
Dictatorship & 0.358 & 0.130 & -0.024 & 0.086 \\
& $(1.30)$ & $(0.81)$ & $(-0.08)$ & $(0.62)$ \\
Overall & $0.745^{* * *}$ & 0.121 & -0.043 & $(-0.02)$ \\
\hline
\end{tabular}


Panel C: Sub-period (2) Jan 1, 2000 - Dec 31, 2008

\begin{tabular}{lcccc}
\hline Portfolios & Low AA & Mixed AA & High AA & Overall \\
\hline \multirow{2}{*}{ Democracy } & 0.238 & -0.008 & 0.173 & 0.101 \\
& $(0.62)$ & $(-0.00)$ & $(0.51)$ & $(0.50)$ \\
Drifter & -0.068 & 0.234 & -0.272 & -0.010 \\
& $(-0.22)$ & $(1.15)$ & $(-1.14)$ & $(-0.07)$ \\
Dictatorship & 0.270 & 0.083 & 0.369 & 0.160 \\
& $(0.83)$ & $(0.46)$ & $(1.18)$ & $(1.03)$ \\
Overall & 0.035 & 0.127 & -0.014 & $(-0.07)$ \\
\hline
\end{tabular}

Table 5

Accruals Reversal (Dechow et al, 1996) and Future Stock Returns

Table 5 reports the portfolios' value-weighted monthly alphas, estimated using the Fama-French (1993) three-factor model and includes the Carhart (1997) momentum factor from WRDS.

$R_{\mathrm{t}}=\alpha+\beta_{1} R M R F_{\mathrm{t}}+\beta_{2} S M B_{\mathrm{t}}+\beta_{3} H M L_{\mathrm{t}}+\beta_{4} U M D_{\mathrm{t}}+\varepsilon_{\mathrm{t}}$

The dependent variable is the value-weighted monthly portfolio excess return $R_{\mathrm{t}}$. The explanatory variables $R M R F, S M B, H M L$ and $U M D$ are the returns to zero-investment portfolios designed to capture market, size, book-to-market, and momentum effects, respectively. The coefficients of these factors are not reported in the table for brevity. The portfolios are sorted two-dimensionally by governance and accruals reversal $A C C R E V_{\mathrm{t}+1}$ (measured as the difference between accruals in the current period and accruals in the previous period, with the accruals being estimated as TACC in equation (3) in Dechow et al. (1996) model) that were described in Section 3. The stocks sorted by governance are reset in September 1990, July 1993, July 1995, February 1998, February 2000, February 2002, January 2004, and January 2006, which are the months when new data on G-Index are available. I extended the sample size of the Democracy (good governance) portfolio in GIM (2003) by including firms with qualitatively similar positive monthly alphas and re-grouping the Democracy portfolio as firms with a G-Index score of 7 or less. Following this, Democracy firms now comprise $27.9 \%$ of the sample on average as compared to the original $9 \%$. Similarly, I re-classified firms with a G-Index of 12 and above as Dictatorship (bad governance), now comprising 20.0\% of the sample on average, as compared to the original $5.5 \%$. The remaining mixed governance firms, termed Drifter, have a G-Index between 8 and 11 and comprise $52.1 \%$ of the sample on average. The magnitude of ACCREV $V_{\mathrm{t}+1}$ is sorted and ranked to form ten decile portfolios three months after the end of each fiscal year to ensure that the financial statements are publicly available, and then they are matched with the monthly CRSP returns in period $t+1$. The portfolio of firms with the lowest (highest) value in ACCREV $V_{t+1}$ is given an accruals reversal score of 1 (10). The group of firms with a score of 3 and below is re-classified as big net negative accruals reversal (Negative Accruals Reversal); those with a score between 4 and 7 are classified as mixed accruals reversal (Mixed Accruals Reversal); and finally, those with a score of 8 and above are classified as big net positive accruals reversal (Positive Accruals Reversal). Panel A describes the overall sample period from September 1990 to December 2008; Panel B is the sub-period from September 1, 1991 to December 31, 1999 as in GIM (2003); and Panel C is the post-GIM sub-period from January 1, 2000 to December 31, 2008. All standard errors are White (1980) robust and the t-statistics are reported in parentheses. Levels of significance are indicated by *,**, *** for 10\%, 5\%, and $1 \%$ respectively.

Panel A: Overall Sample Period Sep 1, 1991 - Dec 31, 2008

\begin{tabular}{lcccc}
\hline Portfolios & $\begin{array}{c}\text { Positive } \\
\text { ACCREV }\end{array}$ & $\begin{array}{c}\text { Mixed } \\
\text { ACCREV }\end{array}$ & $\begin{array}{c}\text { Negative } \\
\text { ACCREV }\end{array}$ & Overall \\
\hline \multirow{2}{*}{ Democracy } & 0.052 & 0.195 & 0.182 & 0.139 \\
& $(0.23)$ & $(1.17)$ & $(0.72)$ & $(1.11)$ \\
Drifter & -0.144 & 0.092 & 0.108 & 0.090 \\
& $(-0.70)$ & $(0.71)$ & $(0.54)$ & $(0.92)$ \\
Dictatorship & 0.052 & $0.182 *$ & 0.000 & 0.117 \\
& $(0.22)$ & $(1.68)$ & $(0.00)$ & $(1.13)$ \\
Overall & -0.061 & 0.123 & 0.100 & $(0.67)$ \\
\hline
\end{tabular}


Panel B: Sub-period (1) Sep 1, 1991 - Dec 31, 1999

\begin{tabular}{lcccc}
\hline Portfolios & $\begin{array}{c}\text { Positive } \\
\text { ACCREV }\end{array}$ & $\begin{array}{c}\text { Mixed } \\
\text { ACCREV }\end{array}$ & $\begin{array}{c}\text { Negative } \\
\text { ACCREV }\end{array}$ & Overall \\
\hline \multirow{2}{*}{ Democracy } & 0.386 & 0.053 & $0.686^{* *}$ & $0.307^{* *}$ \\
& $(1 / 28)$ & $(0.25)$ & $(2.12)$ & $(1.94)$ \\
\multirow{2}{*}{ Drifter } & -0.130 & 0.191 & 0.285 & 0.210 \\
& $(-0.40)$ & $(1.45)$ & $(1.09)$ & $(1.58)$ \\
Dictatorship & -0.027 & 0.142 & 0.004 & 0.086 \\
& $(-0.07)$ & $(1.01)$ & $(1.37)$ & $(0.62)$ \\
Overall & 0.071 & 0.148 & $0.379 * *$ & \\
& $(0.31)$ & $(1.59)$ & $(2.02)$ & \\
\hline
\end{tabular}

Panel C: Sub-period (2) Jan 1, 2000 - Dec 31, 2008

\begin{tabular}{lcccc}
\hline Portfolios & $\begin{array}{c}\text { Positive } \\
\text { ACCREV }\end{array}$ & $\begin{array}{c}\text { Mixed } \\
\text { ACCREV }\end{array}$ & $\begin{array}{c}\text { Negative } \\
\text { ACCREV }\end{array}$ & Overall \\
\hline \multirow{2}{*}{ Democracy } & -0.088 & 0.257 & 0.082 & 0.101 \\
\multirow{2}{*}{ Drifter } & $(-0.26)$ & $(0.95)$ & $(0.21)$ & $(0.50)$ \\
& -0.296 & 0.044 & -0.021 & -0.010 \\
Dictatorship & $(-1.11)$ & $(0.19)$ & $(-0.07)$ & $(-0.07)$ \\
& 0.044 & 0.237 & -0.199 & 0.160 \\
Overall & $(0.14)$ & $(1.37)$ & $(-0.66)$ & $(1.03)$ \\
& -0.196 & 0.111 & 0.060 & \\
\hline
\end{tabular}

Repeating the analysis using the modified Jones model by Dechow et al. (1996) to estimate the abnormal accruals, all the results as shown in Table 4 and 5 are qualitatively similar, although the statistical significance is lost for most of the findings for the overall sample period from 1991-2008. A closer investigation highlights that the results hold true in the original sub-period 1991-1999 in GIM (2003), but the significance has mainly dissipated in the post-GIM sub-period 2000-2008. This is consistent with the findings in Bebchuk et al. (2010) and Green et al. (2008) that the governance effect on performance and the return to the abnormal accruals strategy had largely disappeared in the 2000s due to "learning" by the market participants or to hedge funds deploying excess capital to exploit the signals. Green et al. (2009) further argued that the abnormal accruals trading strategy documented by Sloan (1996) was known to a few in academe but to no practitioners in the preSloan sub-period 4/89-12/95. This pre-Sloan period also coincided with my findings that the AA signal provides incremental value during the sub-period 1991-1999. However, the accruals anomaly took some time to be understood in order for investors to take definite action (Shleifer and Vishny, 1997; Lee, 2001; Mitchell, Pedersen, and Pulvino, 2007). In the post-Sloan-TAR period, Green et al. (2008) pointed out that not only was the accruals anomaly widely known both inside and outside of academe, but during the period, key senior accounting academics such as Charles Lee and Richard Sloan significantly increased their ties to Barclays Global Investors. 
There is also heightened attention by the SEC, the media, and the public in the earnings quality issue in the 2000s, particularly after the various accounting scandals epitomized by the Enron case, and increased regulatory scrutiny such as the passage of the Sarbanes-Oxley Act, or Sarbox (2002), and Regulation Fair Disclosure, or RegFD (1999-2000), and higher incidence of litigation risks associated with abnormal accruals (DuCharme et al., 2004) during this period. These factors could probably account for "lower" opportunistic manipulation of accruals in which the "discretionary" portion could be estimated using the now widely-known modified Jones model (Cohen, Dey, and Lys, 2008; Bartov and Cohen, 2009), resulting in a weaker trading signal, and hence in the decaying return and lack of statistical significance for my sub-period 2000-2008 from the modified Jones model.

\title{
Firm Characteristics and Firm Operating Performance in the Two-dimensional Portfolios
}

\section{Table 6}

\section{Comparison of Firm Characteristics Sorted Two-dimensionally by Governance and Abnormal Accruals for 1991 to 2008}

\begin{abstract}
Table 6 reports the firm characteristics of the three categories of portfolio sorted two-dimensionally by governance and abnormal accruals. Market cap (in millions) is calculated monthly as shares outstanding times the month-end share price. Turnover is the monthly number of shares traded relative to the number of shares outstanding. BM or book-to-market is the book value equity per share relative to the month-end share price. $P E$ or price-earnings ratio is end-of-fiscal-year share price relative to EPS. Div or dividend yield is dividend per share relative to share price. $R O A$ or return on assets is income before extraordinary items relative to average total assets. Leverage is total net debt relative to total assets. $R \& D$ is research and expenditure expense relative to sales. Capexl is capital expenditure relative to sales. Capex 2 is capital expenditure relative to average total assets. Deferred Revenue is deferred current revenue (Compustat item $D R C$ ) relative to average total assets. Special Item is special items relative to average total assets. $N$ is the number of firm-months. Means tests are based on time-series of monthly cross-sectional means. Abnormal Accrual is calculated from the residual in the Dechow and Dichev (2002) model.
\end{abstract}

Panel A: Democracy-Low AA vs. Democracy-High AA

\begin{tabular}{|c|c|c|c|c|c|}
\hline & \multicolumn{2}{|c|}{$\begin{array}{c}\text { Democracy-Low AA } \\
\quad(\mathbf{N}=7887) \\
\end{array}$} & \multicolumn{2}{|c|}{$\begin{array}{c}\text { Democracy-High AA } \\
\quad(N=6913) \\
\end{array}$} & \multirow{2}{*}{$\frac{\text { Means t-test }}{\text { p-value }}$} \\
\hline & Mean & Median & Mean & Median & \\
\hline Market cap & 3675.930 & 630.576 & 4654.919 & 903.396 & $<.01$ \\
\hline Price & 23.712 & 19.625 & 27.472 & 23.438 & $<.01$ \\
\hline Turnover & 1.605 & 1.002 & 1.778 & 1.110 & $<.01$ \\
\hline $\mathrm{BM}$ & 0.615 & 0.461 & 0.496 & 0.380 & $<.01$ \\
\hline $\mathrm{PE}$ & 20.802 & 17.293 & 21.817 & 17.279 & 0.563 \\
\hline Div & 0.015 & 0.000 & 0.009 & 0.000 & $<.01$ \\
\hline Sales Growth & 0.086 & 0.058 & 0.205 & 0.131 & $<.01$ \\
\hline $\mathrm{ROA}_{\mathrm{t}-1}$ & 0.028 & 0.046 & 0.029 & 0.064 & 0.734 \\
\hline $\mathrm{ROA}_{\mathrm{t}}$ & 0.015 & 0.037 & 0.071 & 0.078 & $<.01$ \\
\hline $\mathrm{ROA}_{\mathrm{t}+1}$ & 0.039 & 0.052 & 0.058 & 0.072 & $<.01$ \\
\hline Leverage & 0.073 & 0.047 & 0.061 & 0.044 & $<.01$ \\
\hline $\mathrm{R} \& \mathrm{D}$ & 0.188 & 0.000 & 0.392 & 0.006 & $<.01$ \\
\hline Capex 1 & 0.086 & 0.039 & 0.116 & 0.048 & $<.01$ \\
\hline Capex2 & 0.060 & 0.043 & 0.074 & 0.056 & $<.01$ \\
\hline Deferred Revenue & 0.010 & 0.000 & 0.006 & 0.000 & $<.01$ \\
\hline Special Item & -0.021 & 0.000 & -0.010 & 0.000 & $<.01$ \\
\hline Abnormal accruals & -0.033 & -0.024 & 0.030 & 0.023 & $<.01$ \\
\hline
\end{tabular}


Panel B: Democracy-Low AA vs. Dictatorship-High AA

\begin{tabular}{|c|c|c|c|c|c|}
\hline & \multicolumn{2}{|c|}{$\begin{array}{c}\text { Democracy-Low AA } \\
(\mathbf{N}=\mathbf{7 8 8 7}) \\
\end{array}$} & \multicolumn{2}{|c|}{$\begin{array}{l}\text { Dictatorship-Low AA } \\
\quad(\mathrm{N}=\mathbf{4 0 8 5})\end{array}$} & \multirow{2}{*}{$\frac{\text { Means t-tes }}{\text { p-value }}$} \\
\hline & Mean & Median & Mean & Median & \\
\hline Market cap & 3675.930 & 630.576 & 3787.157 & 1039.968 & 0.712 \\
\hline Price & 23.712 & 19.625 & 28.621 & 25.25 & $<.01$ \\
\hline Turnover & 1.605 & 1.002 & 1.117 & 0.821 & $<.01$ \\
\hline $\mathrm{BM}$ & 0.615 & 0.461 & 0.579 & 0.458 & 0.060 \\
\hline PE & 20.802 & 17.293 & 28.336 & 17.588 & $<.01$ \\
\hline Div & 0.015 & 0.000 & 0.024 & 0.016 & $<.01$ \\
\hline Sales Growth & 0.086 & 0.058 & 0.079 & 0.042 & 0.242 \\
\hline $\mathrm{ROA}_{\mathrm{t}-1}$ & 0.028 & 0.046 & 0.032 & 0.039 & 0.034 \\
\hline $\mathrm{ROA}_{\mathrm{t}}$ & 0.015 & 0.037 & 0.027 & 0.032 & $<.01$ \\
\hline $\mathrm{ROA}_{t+1}$ & 0.039 & 0.052 & 0.047 & 0.048 & $<.01$ \\
\hline Leverage & 0.073 & 0.047 & 0.203 & 0.232 & $<.01$ \\
\hline$R \& D$ & 0.188 & 0.000 & 0.039 & 0.006 & $<.01$ \\
\hline Capex 1 & 0.086 & 0.039 & 0.053 & 0.034 & $<.01$ \\
\hline Capex2 & 0.060 & 0.043 & 0.049 & 0.039 & $<.01$ \\
\hline Deferred Revenue & 0.010 & 0.000 & 0.004 & 0.000 & $<.01$ \\
\hline Special Item & -0.021 & 0.000 & -0.019 & -0.003 & 0.125 \\
\hline Abnormal accruals & -0.033 & -0.024 & -0.027 & -0.020 & $<.01$ \\
\hline
\end{tabular}

Panel C: Drifter-Low AA vs. Drifter-High AA

\begin{tabular}{|c|c|c|c|c|c|}
\hline & \multicolumn{2}{|c|}{$\begin{array}{c}\text { Drifter-Low AA } \\
(\mathbf{N}=12167)\end{array}$} & \multicolumn{2}{|c|}{$\begin{array}{c}\text { Drifter-High AA } \\
\quad(\mathbf{N}=10913)\end{array}$} & \multirow{2}{*}{$\begin{array}{c}\text { Means t-test } \\
\text { p-value }\end{array}$} \\
\hline & Mean & Median & Mean & Median & \\
\hline Market cap & 4455.748 & 916.934 & 4007.792 & 950.213 & $<.01$ \\
\hline Price & 26.627 & 21.930 & 27.391 & 22.880 & 0.073 \\
\hline Turnover & 1.694 & 1.120 & 1.650 & 1.033 & $<.01$ \\
\hline $\mathrm{BM}$ & 0.558 & 0.445 & 0.523 & 0.422 & $<.01$ \\
\hline PE & 11.477 & 15.834 & 16.175 & 16.169 & 0.037 \\
\hline Div & 0.013 & 0.000 & 0.012 & 0.000 & $<.01$ \\
\hline Sales Growth & 0.056 & 0.041 & 0.171 & 0.103 & $<.01$ \\
\hline $\mathrm{ROA}_{\mathrm{t}-1}$ & 0.017 & 0.040 & 0.025 & 0.051 & $<.01$ \\
\hline $\mathrm{ROA}_{\mathrm{t}}$ & 0.003 & 0.031 & 0.054 & 0.064 & $<.01$ \\
\hline $\mathrm{ROA}_{t+1}$ & 0.033 & 0.047 & 0.041 & 0.057 & $<.01$ \\
\hline Leverage & 0.109 & 0.115 & 0.106 & 0.124 & 0.453 \\
\hline $\mathrm{R} \& \mathrm{D}$ & 0.243 & 0.013 & 0.311 & 0.014 & 0.288 \\
\hline Capex 1 & 0.070 & 0.038 & 0.096 & 0.045 & $<.01$ \\
\hline Capex2 & 0.054 & 0.039 & 0.065 & 0.050 & $<.01$ \\
\hline Deferred Revenue & 0.011 & 0.000 & 0.007 & 0.000 & $<.01$ \\
\hline Special Item & -0.027 & -0.003 & -0.013 & 0.000 & $<.01$ \\
\hline Abnormal accruals & -0.031 & -0.022 & 0.029 & 0.022 & $<.01$ \\
\hline
\end{tabular}


Panel D: Democracy-High AA vs. Dictatorship-High AA

\begin{tabular}{|c|c|c|c|c|c|}
\hline & \multicolumn{2}{|c|}{$\begin{array}{c}\text { Democracy-High AA } \\
\quad(N=6913)\end{array}$} & \multicolumn{2}{|c|}{$\begin{array}{l}\text { Dictatorship-High AA } \\
\quad(\mathbf{N}=\mathbf{3 5 8 6})\end{array}$} & \multirow{2}{*}{$\frac{\text { Means t-tes }}{\text { p-value }}$} \\
\hline & Mean & Median & Mean & Median & \\
\hline Market cap & 4654.919 & 903.396 & 5835.055 & 1381.182 & $<.01$ \\
\hline Price & 27.472 & 23.438 & 31.896 & 28.125 & $<.01$ \\
\hline Turnover & 1.778 & 1.110 & 1.158 & 0.752 & $<.01$ \\
\hline BM & 0.496 & 0.380 & 0.508 & 0.451 & 0.387 \\
\hline PE & 21.817 & 17.279 & 17.283 & 15.227 & $<.01$ \\
\hline Div & 0.009 & 0.000 & 0.019 & 0.016 & $<.01$ \\
\hline Sales Growth & 0.205 & 0.131 & 0.109 & 0.085 & $<.01$ \\
\hline $\mathrm{ROA}_{\mathrm{t}-1}$ & 0.029 & 0.064 & 0.048 & 0.052 & $<.01$ \\
\hline $\mathrm{ROA}_{\mathrm{t}}$ & 0.071 & 0.078 & 0.064 & 0.063 & $<.01$ \\
\hline $\mathrm{ROA}_{t+1}$ & 0.058 & 0.072 & 0.055 & 0.059 & 0.285 \\
\hline Leverage & 0.061 & 0.044 & 0.184 & 0.204 & $<.01$ \\
\hline$R \& D$ & 0.392 & 0.006 & 0.030 & 0.007 & $<.01$ \\
\hline Capex 1 & 0.116 & 0.048 & 0.056 & 0.041 & $<.01$ \\
\hline Capex2 & 0.074 & 0.056 & 0.055 & 0.048 & $<.01$ \\
\hline Deferred Revenue & 0.006 & 0.000 & 0.000 & 0.000 & $<.01$ \\
\hline Special Item & -0.010 & 0.000 & -0.011 & 0.000 & 0.177 \\
\hline Abnormal accruals & 0.030 & 0.023 & 0.027 & 0.022 & $<.01$ \\
\hline
\end{tabular}

Panel E: Dictatorship-Low AA vs. Dictatorship-High AA

\begin{tabular}{|c|c|c|c|c|c|}
\hline & \multicolumn{2}{|c|}{$\begin{array}{c}\text { Dictatorship-Low AA } \\
\quad(N=4085)\end{array}$} & \multicolumn{2}{|c|}{$\begin{array}{l}\text { Dictatorship-High AA } \\
\quad(\mathbf{N}=\mathbf{3 5 8 6}) \\
\end{array}$} & \multirow{2}{*}{$\frac{\text { Means t-tes }}{\text { p-value }}$} \\
\hline & Mean & Median & Mean & Median & \\
\hline Market cap & 3787.157 & 1039.968 & 5835.055 & 1381.182 & $<.01$ \\
\hline Price & 28.621 & 25.25 & 31.896 & 28.125 & $<.01$ \\
\hline Turnover & 1.117 & 0.821 & 1.158 & 0.752 & $<.01$ \\
\hline $\mathrm{BM}$ & 0.579 & 0.458 & 0.508 & 0.451 & $<.01$ \\
\hline PE & 28.336 & 17.588 & 17.283 & 15.227 & $<.01$ \\
\hline Div & 0.024 & 0.016 & 0.019 & 0.016 & $<.01$ \\
\hline Sales Growth & 0.079 & 0.042 & 0.109 & 0.085 & $<.01$ \\
\hline $\mathrm{ROA}_{\mathrm{t}-1}$ & 0.032 & 0.039 & 0.048 & 0.052 & $<.01$ \\
\hline $\mathrm{ROA}_{\mathrm{t}}$ & 0.027 & 0.032 & 0.064 & 0.063 & $<.01$ \\
\hline $\mathrm{ROA}_{\mathrm{t}+1}$ & 0.047 & 0.048 & 0.055 & 0.059 & $<.01$ \\
\hline Leverage & 0.203 & 0.232 & 0.184 & 0.204 & $<.01$ \\
\hline$R \& D$ & 0.039 & 0.006 & 0.030 & 0.007 & $<.01$ \\
\hline Capex 1 & 0.053 & 0.034 & 0.056 & 0.041 & 0.129 \\
\hline Capex2 & 0.049 & 0.039 & 0.055 & 0.048 & $<.01$ \\
\hline Deferred Revenue & 0.004 & 0.000 & 0.000 & 0.000 & $<.01$ \\
\hline Special Item & -0.019 & -0.003 & -0.011 & 0.000 & $<.01$ \\
\hline Abnormal accruals & -0.027 & -0.020 & 0.027 & 0.022 & $<.01$ \\
\hline
\end{tabular}


In this section, I explore the return on the two-dimensional portfolios in greater depth by examining their firm characteristics. In Table 6, I make comparisons between five pairs of portfolios: (1) DemocracyLow AA (Super-Performers) vs. Democracy-High AA portfolios, so as to attempt to find out the source of the incremental value in the AA signal in the firm characteristics; (2) Democracy-Low AA (SuperPerformers) vs. Dictatorship-Low AA to assess the incremental value in the governance signal; (3) Drifter-Low AA vs. Drifter-High AA, so as to assess what are so different in the firm-characteristics between these two sets of firms beyond the Fama-French-Carhart factors, given that the results that the hedge abnormal return can be economically substantial at $13.7 \%$ per year; (4) Democracy-High $A A$ vs. Dictatorship-High AA, since firms with high abnormal accruals - conventionally interpreted as poor earnings quality - are expected to be associated with negative future return, but Democracy-High $A A$ firms can instead have positive return, with a question of whether there could be any systematic similarities or differences in firm-characteristics that explain this; and finally (5) Dictatorship-Low AA vs. Dictatorship-High AA, since it is surely an oddity for firms with poor governance structures to be associated with positive return if they are also accompanied by Low $A A$, and investigating the firmcharacteristics could perhaps prove fruitful in re-looking into possible instances of "good" managerial entrenchment.

First, in the comparison between firms in Democracy-Low AA (Super-Performers) and DemocracyHigh AA in Table 6, Super-Performers are relatively smaller in size with a median (mean) market cap at $\$ 630$ million ( $\$ 3.7$ billion) versus $\$ 903$ million ( $\$ 4.7$ billion) for Democracy-High AA firms. Also, Super-Performers have a relatively lower share price, lower turnover, higher book-to-market ratio, relatively similar PE ratio, higher dividend yield, lower sales growth, lower ROA, slightly more leverage, lower $\mathrm{R} \& \mathrm{D}$ and capex, higher deferred revenue, and larger negative special items. There is no difference in operating performance in the previous year, while there is an improvement (deterioration) in ROA in the following year for Super-Performers (Democracy-Low AA). Second, as compared to Dictatorship-Low AA, Super-Performers are similar in size, have lower share price, higher turnover, slightly higher book-to-market ratio, lower PE, lower dividend yield, quite similar sales growth, lower ROA, lower leverage, higher R\&D and capex, and higher deferred revenue. There is a slightly lower operating performance in the previous year for Democracy-Low AA, while there is an improvement in ROA in the following year for both. Interestingly, higher capex investments in the hands of the managers at these Super-Performers do not lead to a poor stock return as was suggested by Titman et al. (2004).

The results appear to suggest that Super-Performers could be "turnaround-stocks" as they have larger negative special items (such as a one-time non-cash restructuring write-off) and better subsequent operating performance. Thus, their outsized performance could be due to investors failing to understand the transitory nature of negative non-cash special items, pronouncing the return from the low accruals anomaly, according to the arguments in Dechow and Ge (2006). In the discussion the paper by Dechow and Ge, Fairfield (2006) noted that "the evidence raise questions about the source of the improved accounting performance ... return on assets for the low accrual/negative special items firms may increase for various reasons - the lower asset base from the write-off, the absence of negative special items in the following year, or higher 'core earnings' in the following year. Because Dechow and Ge do not control for the effect of the denominator and do not separate future earnings into its core and special components, the evidence does not demonstrate conclusively that the firms recover in any meaningful sense ... poorly performing firms and negative accrual firms are not identical sets, but the authors did not differentiate between the two." 
As mentioned earlier, Super-Performers include well-known, institutional big-cap stocks, such as Coca-Cola Co, formed in the portfolio at various months in 1991-2008. Using Coca-Cola as an example, ${ }^{(18)}$ I find that the excess returns are mainly from the 1990-1991, 1994-1997 and 2006 periods. Roberto Goizueta took over the reins of the CEO in 1985 and Coca-Cola embarked upon one of the most famous marketing blunders in corporate America history by launching the sweeter "New Coke" to compete with Pepsi for the "younger" taste buds. "New Coke" was booed with negative publicity and prompted the reversal back to "Classic Coke". Coca-Cola sold the non-core entertainment business Columbia Pictures, purchased by Goizueta in 1982, to Sony for $\$ 3$ billion in 1989. After the restructurings, the company emerged stronger from its earlier blunders and re-established itself as the pacesetter in the non-alcoholic beverage industry during the 1990s. ${ }^{(19)}$

In 1990, the company opened the "World of Coca Cola" museum in Atlanta to retell its heritage; subsequently excess returns were generated in 1990-1991. The popular "Always Coca-Cola" advertising campaign was introduced in 1993, and the world met with the lovable Coca-Cola Polar Bear for the first time. Coca-Cola also became a major sponsor of the Olympics and enjoyed a high profile during the 1996 Olympic Games. By 1997, 1 billion Coca-Cola products were sold every day - and 1997 was also the year of the death of its iconic CEO Goizueta; excess returns were generated in 1994-1997. One of Goizueta's notable accomplishments was to help Coca-Cola realize its goal to develop a diet version of Coke in 1982; The déjà-vu launch of Coke Zero, the popular zero calorie cola came in 2005, and with it excess returns were generated in 2006.

And all these corporate actions took place in a Democracy governance structure at Coca-Cola, suggesting that corporate governance could be the important joint factor that Fairfield (2006) questioned about to determine whether the low accrual firms with negative special items "recover in any meaningful sense." As pointed out in the Empirical Results Section, the 10.5\% abnormal return per year over 1991-2008 for Super-Performers (low accruals firms with good governance) is higher than the return for the unconditional low accruals portfolio (6.6\%), indicating that the incremental value in the good governance signal is $3.9 \%$, and that the complementarity in governance and accruals information is important in determining returns predictability and the persistence in longer-term firm performance.

Third, Drifter-Low AA are slightly bigger in size than Drifter-High AA, have quite a similar share price, slightly higher turnover, slightly higher book-to-market, quite similar PE ratio, slightly higher dividend yield, lower sales growth, lower ROA, quite similar leverage, quite similar R\&D, lower capex, higher deferred revenue, and larger negative special items. There is a slightly lower operating performance in the previous year for Drifter-Low $A A$, while there is an improvement (deterioration) in ROA in the following year for Drifter-Low AA (Drifter-High AA). The "restructuring effect" is probably at work again for the positive abnormal return at Drifter-Low AA with large negative special items. Interestingly, it also further reinforces the importance of governance quality in determining the persistence in longer-term firm performance since Super-Performers (low accruals firms with good governance) generate 4.3\% per year more in abnormal return over 1991-2008 than Drifter with similarly negative accruals and negative special items.

Fourth, Democracy-High AA are smaller in size than Dictatorship-High AA, have a lower share price, higher turnover, quite similar book-to-market ratio, higher PE ratio, lower dividend yield, higher sales growth, higher ROA, lower leverage, higher R\&D and capex, higher deferred revenue, and 
quite similar negative special items. There is a mixed operating performance in the previous year for Democracy-Low AA, while there is deterioration in ROA in the following year for both. The results appear to suggest that booking higher sales growth and larger corporate investments (capex and R\&D) are regarded as a genuine attempt by the managers to increase shareholders' wealth even if it increases abnormal accruals and impacts short-term operating performance (lower ROA in the following year) at the Democracy-High AA firms, and hence their future return is not negative (although not significantly positive) as predicted under Sloan.

Fifth, Dictatorship-Low AA are smaller in size than Dictatorship-High AA, have a lower share price, slightly lower turnover, higher book-to-market ratio, higher PE ratio, higher dividend yield, lower sales growth, lower ROA, higher leverage, slightly higher R\&D, slightly lower capex, higher deferred revenue, and larger negative special items. There is a slightly lower operating performance in the previous year for Dictatorship-Low AA, while there is an improvement (deterioration) in ROA in the following year for Dictatorship-Low AA (Dictatorship-High AA). This appears to suggest that the supposed "entrenched" managers at Dictatorship-Low AA are probably achievers who want a "quiet life" and they produce a higher future operating performance and pay a higher dividend yield to shareholders. This is different from the results in Bertrand and Mullainathan (2003) that show profitability declined in the firms run by "quiet-life" entrenched managers. The reason is likely because the incremental value in the AA signal helps in separating the quiet-performing managers from the "quietly" destructive entrenched managers who produce a discordantly poor future operating performance.

\section{ROBUSTNESS TEST}

Kraft, Leone, and Wasley (2006) document a "look-ahead bias" in many accruals studies. Because many studies using the Dechow and Dichev (2002) model were interested in examining the evolution of accruals as well as the stock returns to an accruals-based trading strategy, the sample selection required that the next year's cash flow from operations be present. But whether or not the numbers are present in the next year is not known at the time of portfolio formation, so the documented return is not the result of an implementable trading strategy. Kraft et al. (2006) show in a sample of NYSE/AMEX firms that the return to the low accrual portfolio is $4.2 \%$ with the bias present, but only $1.8 \%$ without it.

I investigate further this "look-ahead bias" by removing the term $C F O_{t+1}$ in equation (2) and running the modified regression model which is comprised of only historical accounting data known at the portfolio formation date. In Table 7 and 8 , I find that all of my results are strikingly very similar, although the magnitude of the abnormal return to the Super-Performers is reduced to $6.5 \%$ per year (t-statistics 1.92) for 1991-2008 as compared to $10.5 \%$ in the original model. The abnormal return to the unconditional Low AA portfolio is reduced slightly to $5.7 \%$ per year (t-statistics 2.24 ) from $6.4 \%$. The Drifter-Low AA portfolio has a slight increase in abnormal return to $6.6 \%$ per year (t-statistics 1.84) from $6.2 \%$, although the significance is lowered. In addition, the abnormal return to the Drifter$H i g h A A$ portfolio is negative at $3.0 \%$ per year, as compared to minus $7.5 \%$ in the original model, and is no longer significant. The positive abnormal return to the Negative ACCREV-Democracy portfolio is reduced slightly to $9.4 \%$ per year (t-statistics 2.09 ) for 1991-2008 as compared to $10.8 \%$. In short, the trading strategy still remains viable economically and statistically. 
Table 7

\section{Monthly Alphas of Portfolios Sorted Two-dimensionally by Governance and Abnormal Accruals (Dechow and Dichev, 2002, without "look-ahead bias")}

Table 7 reports the portfolios' value-weighted monthly alphas, estimated using Fama-French (1993) three-factor model and includes the Carhart (1997) momentum factor from WRDS.

$R_{\mathrm{t}}=\alpha+\beta_{1} R M R F_{\mathrm{t}}+\beta_{2} S M B_{\mathrm{t}}+\beta_{3} H M L_{\mathrm{t}}+\beta_{4} U M D_{\mathrm{t}}+\varepsilon_{\mathrm{t}}$

The dependent variable is the value-weighted monthly portfolio excess return $R_{t}$. The explanatory variables $R M R F, S M B, H M L$ and $U M D$ are the returns to zero-investment portfolios designed to capture market, size, book-to-market, and momentum effects, respectively. The coefficients of these factors are not reported in the table for brevity. Stocks formed in the portfolios are sorted two-dimensionally by governance and abnormal accruals (AA, measured by the Dechow and Dichev (2002) model). Stocks sorted by governance are reset in September 1990, July 1993, July 1995, February 1998, February 2000, February 2002, January 2004, and January 2006, which are the months when new data on G-Index are available. I extended the sample size of the Democracy (good governance) portfolio in GIM (2003) by including firms with qualitatively similar positive monthly alphas and re-grouping the Democracy portfolio as firms with a G-Index score of 7 or less. Following this, Democracy firms now comprise $27.9 \%$ of the sample on average as compared to the original 9\%. Similarly, I re-classified firms with a G-Index of 12 and above as Dictatorship (bad governance), now comprising $20.0 \%$ of the sample on average, as compared to the original $5.5 \%$. The remaining mixed governance firms, termed Drifter, have a G-Index between 8 and 11 and comprise $52.1 \%$ of the sample on average. For the stocks sorted by EQ, ten decile portfolios ranked by the magnitude of the residuals in the Dechow and Dichev (2002) model are formed three months after the end of each fiscal year to ensure that the financial statements are publicly available. The portfolio of firms with the lowest (highest) value in residuals is given an AA score of 1 (10). Similar to the approach used in sorting the firms into the three categories of governance structures, the group of firms with a score of 3 and below is re-classified as "Low or Income-Decreasing Abnormal Accruals (AA)"; those with a score between 4 and 7 are classified as "Mixed AA"; and finally, those with a score of 8 and above are classified as "High or Income-Increasing AA". Panel A describes the overall sample period from September 1990 to December 2008; Panel B is the sub-period from September 1, 1991 to December 31, 1999 as in GIM (2003); and Panel C is the post-GIM subperiod from January 1, 2000 to December 31, 2008. All standard errors are White (1980) robust and the t-statistics are reported in parentheses. Levels of significance are indicated by $*, * *, * *$ for $10 \%, 5 \%$, and $1 \%$ respectively.

Panel A: Overall Sample Period Sep 1, 1991 - Dec 31, 2008

\begin{tabular}{lllll}
\hline Portfolios & Low AA & Mixed AA & High AA & Overall \\
\hline \multirow{2}{*}{ Democracy } & $0.543^{* *}$ & -0.053 & 0.309 & 0.213 \\
& $(1.92)$ & $(-0.21)$ & $(0.90)$ & $(1.15)$ \\
Drifter & $0.549 *$ & 0.060 & -0.253 & 0.054 \\
& $(1.84)$ & $(0.46)$ & $(-1.05)$ & $(0.41)$ \\
Dictatorship & 0.278 & -0.158 & 0.163 & 0.007 \\
& $(1.10)$ & $(-0.95)$ & $(0.57)$ & $(0.05)$ \\
Overall & $0.473 * *$ & -0.043 & 0.010 & \\
\hline
\end{tabular}

Panel B: Sub-period (1) Sep 1, 1991 - Dec 31, 1999

\begin{tabular}{lllll}
\hline Portfolios & Low AA & Mixed AA & High AA & Overall \\
\hline \multirow{2}{*}{ Democracy } & $0.712 *$ & -0.201 & $0.652 *$ & 0.194 \\
& $(1.85)$ & $(-0.57)$ & $(1.72)$ & $(0.92)$ \\
Drifter & $0.739 *$ & 0.072 & -0.312 & 0.057 \\
& $(1.91)$ & $(0.44)$ & $(-0.84)$ & $(0.38)$ \\
Dictatorship & 0.416 & -0.017 & 0.093 & 0.061 \\
& $(1.35)$ & $(-0.10)$ & $(0.24)$ & $(0.40)$ \\
Overall & $0.691 * * *$ & -0.073 & 0.196 & \\
\hline
\end{tabular}


Panel C: Sub-period (2) Jan 1, 2000 - Dec 31, 2008

\begin{tabular}{lllll}
\hline Portfolios & Low AA & Mixed AA & High AA & Overall \\
\hline \multirow{2}{*}{ Democracy } & 0.246 & 0.253 & 0.307 & 0.275 \\
& $(0.59)$ & $(0.67)$ & $(0.52)$ & $(0.93)$ \\
Drifter & 0.437 & 0.178 & -0.138 & 0.154 \\
& $(0.92)$ & $(0.83)$ & $(-0.42)$ & $(0.70)$ \\
Dictatorship & 0.072 & -0.165 & 0.445 & 0.028 \\
\multirow{2}{*}{ Overall } & $(0.19)$ & $(-0.57)$ & $(1.05)$ & $(0.12)$ \\
\hline
\end{tabular}

Table 8

\section{Accruals Reversal (Dechow and Dichev, 2002, without "look-ahead bias") and Future Stock Returns}

Table 8 reports the portfolios' value-weighted monthly alphas, estimated using the Fama-French (1993) three-factor model and includes the Carhart (1997) momentum factor from WRDS.

$R_{\mathrm{t}}=\alpha+\beta_{1} R M R F_{\mathrm{t}}+\beta_{2} S M B_{\mathrm{t}}+\beta_{3} H M L_{\mathrm{t}}+\beta_{4} U M D_{\mathrm{t}}+\varepsilon_{\mathrm{t}}$

The dependent variable is the value-weighted monthly portfolio excess return $R_{i}$. The explanatory variables $R M R F, S M B, H M L$ and $U M D$ are the returns to zero-investment portfolios designed to capture market, size, book-to-market, and momentum effects, respectively. The coefficients of these factors are not reported in the table for brevity. The portfolios are sorted two-dimensionally by governance and accruals reversal $A C C R E V_{\mathrm{t}+1}$ (measured as the difference between accruals in the current period and accruals in the previous period, with the accruals being estimated as $\Delta W C$ in equation (2) in Dechow and Dichev (2002) model) that were described in Section 3. The stocks sorted by governance are reset in September 1990, July 1993, July 1995, February 1998, February 2000, February 2002, January 2004, and January 2006, which are the months when new data on G-Index are available. I extended the sample size of the Democracy (good governance) portfolio in GIM (2003) by including firms with qualitatively similar positive monthly alphas and re-grouping the Democracy portfolio as firms with a G-Index score of 7 or less. Following this, Democracy firms now comprise $27.9 \%$ of the sample on average as compared to the original $9 \%$. Similarly, I re-classified firms with a G-Index of 12 and above as Dictatorship (bad governance), now comprising 20.0\% of the sample on average, as compared to the original $5.5 \%$. The remaining mixed governance firms, termed Drifter, have a G-Index between 8 and 11 and comprise $52.1 \%$ of the sample on average. The magnitude of $A C C R E V_{\mathrm{t}+1}$ is sorted and ranked to form ten decile portfolios three months after the end of each fiscal year to ensure that the financial statements are publicly available, and then they are matched with the monthly CRSP returns in period $t+1$. The portfolio of firms with the lowest (highest) value in $A C C R E V_{t+1}$ is given an accruals reversal score of 1 (10). The group of firms with a score of 3 and below is re-classified as big net negative accruals reversal (Negative Accruals Reversal); those with a score between 4 and 7 are classified as mixed accruals reversal (Mixed Accruals Reversal); and finally, those with a score of 8 and above are classified as big net positive accruals reversal (Positive Accruals Reversal). Panel A describes the overall sample period from September 1990 to December 2008; Panel B is the sub-period from September 1, 1991 to December 31, 1999 as in GIM (2003); and Panel C is the post-GIM sub-period from January 1, 2000 to December 31, 2008. All standard errors are White (1980) robust and the t-statistics are reported in parentheses. Levels of significance are indicated by *,**, *** for 10\%, 5\%, and $1 \%$ respectively.

Panel A: Overall Sample Period Sep 1, 1991 - Dec 31, 2008

\begin{tabular}{lllll}
\hline \multirow{2}{*}{ Portfolios } & $\begin{array}{l}\text { Positive } \\
\text { ACCREV }\end{array}$ & $\begin{array}{l}\text { Mixed } \\
\text { ACCREV }\end{array}$ & $\begin{array}{l}\text { Negative } \\
\text { ACCREV }\end{array}$ & Overall \\
\hline \multirow{2}{*}{ Democracy } & 0.258 & 0.040 & $0.787 * *$ & 0.213 \\
& $(0.79)$ & $(0.21)$ & $(2.09)$ & $(1.15)$ \\
\multirow{2}{*}{ Drifter } & 0.139 & 0.016 & 0.095 & 0.054 \\
& $(0.55)$ & $(0.12)$ & $(0.39)$ & $(0.41)$ \\
Dictatorship & 0.180 & 0.074 & -0.146 & 0.007 \\
& $(0.68)$ & $(0.44)$ & $(-0.52)$ & $(0.05)$ \\
Overall & 0.190 & 0.011 & 0.209 & \\
\hline
\end{tabular}


Panel B: Sub-period (1) Sep 1, 1991 - Dec 31, 1999

\begin{tabular}{lllll}
\hline \multirow{2}{*}{ Portfolios } & $\begin{array}{l}\text { Positive } \\
\text { ACCREV }\end{array}$ & $\begin{array}{l}\text { Mixed } \\
\text { ACCREV }\end{array}$ & $\begin{array}{l}\text { Negative } \\
\text { ACCREV }\end{array}$ & Overall \\
\hline \multirow{2}{*}{ Democracy } & $0.701^{*}$ & -0.025 & 0.564 & 0.194 \\
\multirow{2}{*}{ Drifter } & $(1.87)$ & $(-0.09)$ & $(1.36)$ & $(0.92)$ \\
& -0.129 & 0.143 & 0.164 & 0.057 \\
\multirow{2}{*}{ Dictatorship } & $(-0.37)$ & $(0.91)$ & $(0.49)$ & $(0.38)$ \\
\multirow{2}{*}{ Overall } & -0.075 & 0.213 & 0.170 & 0.061 \\
& $(-0.19)$ & $(0.92)$ & $(0.46)$ & $(0.40)$ \\
& 0.244 & 0.071 & 0.141 & \\
\hline
\end{tabular}

Panel C: Sub-period (2) Jan 1, 2000 - Dec 31, 2008

\begin{tabular}{lllll}
\hline \multirow{2}{*}{ Portfolios } & $\begin{array}{l}\text { Positive } \\
\text { ACCREV }\end{array}$ & $\begin{array}{l}\text { Mixed } \\
\text { ACCREV }\end{array}$ & $\begin{array}{l}\text { Negative } \\
\text { ACCREV }\end{array}$ & Overall \\
\hline \multirow{2}{*}{ Democracy } & 0.097 & 0.010 & $1.051^{*}$ & 0.275 \\
& $(0.18)$ & $(0.04)$ & $(1.67)$ & $(0.93)$ \\
\multirow{2}{*}{ Drifter } & 0.241 & 0.037 & 0.152 & 0.154 \\
& $(0.62)$ & $(0.16)$ & $(0.41)$ & $0.70)$ \\
\multirow{2}{*}{ Dictatorship } & 0.462 & 0.088 & -0.289 & 0.028 \\
\multirow{2}{*}{ Overall } & $(1.24)$ & $(0.35)$ & $(-0.64)$ & $(0.12)$ \\
& 0.144 & 0.023 & 0.307 & \\
\hline
\end{tabular}

Interestingly, the results also reinforced the importance of the prospective cash flow from operations information, since its inclusion in the regression model to estimate abnormal accruals greatly enhances the magnitude of the future abnormal return. Dechow, Richardson and Sloan (2008) conjectured it is the use of cash, rather than the raising or the distribution of financing, that leads to predictable returns. Information of next-period's cash flow from operations can reveal much about the use of cash, and market participants can assess whether managers have been credible in what they have communicated in the previous period(s) on how they intend to utilize cash in investment projects, and my results in this robustness test support the argument in Dechow et al. (2008).

\section{SUMMARY AND CONCLUSION}

The signals of corporate governance and abnormal accruals are akin to the bow and arrow in a complementarity relationship, resolving the uncertainty associated with what each signal can reveal on a stand-alone basis about firm performance and its future prospects, as well as aiding in the understanding of whether managers exercise accounting discretion in an opportunistic or efficient manner. The bow (governance signal) without the arrow (abnormal accruals signal) is not effective and the governance effect on returns is attenuated to no different from zero when the firms with both good governance and low abnormal accruals (AA) are removed. Similarly, the arrow without the bow cannot shoot sufficiently far or sharply to yield an outsized abnormal future return; Super-Performers, the firms with both good governance and Low AA, can generate an abnormal return of $10.5 \%$ per year over 1991-2008, as compared to the 3.5 and $6.4 \%$ for the unconditional good governance and Low $A A$ firms respectively, illuminating the incremental value in what each signal can bring to each 
other. Together, the unique pairing of the "arrow" and the "bow" contributes to the total information environment to separate winners from losers.

The orthodox view since Sloan (1996) that high accruals are associated with negative future stock return has resulted in high accruals to be widely interpreted as evidence of earnings management or poor earnings quality. The Icarus manager, exalted by his flight when flying the pair of flexible accruals wax wings based upon the revenue recognition and matching principles, was flying too high and too near to the blazing sun, which softened the wax that held the feathers together. Daedalus cried out to his son that the wings were built for a higher purpose than his self-satisfaction; Icarus ignored the teachings of his father and flew higher, thinking his wings made him the equal of the gods. The pair of wings came off, and Icarus plunged into the sea, akin to the extreme accruals reversal and the "consequent" negative future stock return. Thus, the Icarus-managers' accounting accruals discretion need to be curbed, since investors cannot unravel the valuation effect of reported earnings in a timely manner under current reporting standards.

Such a dominant view has not been questioned before (Christie and Zimmerman, 1996; Louis and Robinson, 2005; Bowen et al., 2008), although it is not uncommon. Most forgot that it was Icarus, Daedalus' son, who sank, not Daedalus himself. Daedalus escaped King Midas' labyrinth and was the only mortal to fly without divine assistance. Healy and Whalen (1999) believe in the importance of identifying and explaining "which types of accruals are used for earnings management and which are not." My results raise doubts that investors respond in the same manner to abnormal accruals, since Democracy firms with high or extreme income-increasing AA have positive future return. This suggests two things: one, the level of abnormal accruals is a coarse measure of earnings manipulation for this set of firms, although it appears to remain a reasonable proxy of earnings management or earnings quality for firms with mixed or poor governance structures; and two, shareholders benefit from "earnings management" because the high accruals signals future performance (e.g. Subramanyam, 1996; Chaney et al., 1996). The evidence helps in the understanding of investor behavior and in whether the policy recommendations in Richardson et al. $(2005,2006)$ and FASB to curtail the use of "less reliable" components of accruals are appropriate, especially for Democracy firms. If the joint interactive signal of governance and abnormal accruals can be a more informative measure of firm performance, reforms to limit managerial flexibility may be counterproductive and an "Icarus paradox."

This study is also the first, to the best of my knowledge, to investigate the properties of the mixed governance (Drifter) firms, the group of firms unexamined in prior literature, even though it forms the bulk of the sample size. I document the fact that Drifter firms can have abnormal future returns as well - if the AA signal is combined interactively with the Drifter signal: the excess return at DrifterLow AA is 6.2 per year over 1991-2008 while that at Drifter-High AA is a negative $7.5 \%$ per year. In addition, the results restore economic viability to the long position of both the governance and abnormal accruals trading strategy, which can be important given short-selling constraints in the short position. My paper also contributes to the resolution of the highly debated issue in the governance literature by showing how both the supporters and critics of the governance effects on returns in GIM (2003) are not incorrect when the governance signal is interactively combined with the abnormal accruals information to yield unique information about the future prospects of the firm. 
The explicit use of accounting information in contracts between management and financiers represents probably the most visible use of accounting information in the governance mechanisms (Sloan, 2001). The results in my paper suggest that the design of managerial compensation requires obtaining performance measures that do not rely solely on earnings. Financiers require the firm to have a governance structure that will credibly elicit the managers' private information. It is rare to observe in practice the use of both earnings and governance measures in contracting. Thus, my results suggest that the inclusion of both measures could result in more efficient contracting.

Finally, this paper highlights the salient fact that it is difficult to apply any one single measure, such as governance or abnormal accruals, on a stand-alone basis to assess firm value and performance, as not only are they one of a multitude of pieces of information of possible interest about firms' quality, but they also interact with one another to resolve informational uncertainty about what each signal can reveal on its own. An investor considers a wide array of contextual information to continually rebalance his or her portfolio (Amir and Lev, 1996; Shevlin, 1996; Beneish, Lee, and Tarpley, 2001; Sloan, 2001; Sorensen, Hua, and Qian, 2005). Interestingly, my paper underscores the value of skillful fundamental analyses in moving away from generic strategies by combining different contextual information - governance information in this study - and looking through this lens to reach fresh insights in equity valuation. This is especially pertinent in a trading environment where large quantitative-oriented hedge funds pursue a similar strategy resulting in correlated performance and a destructive destabilizing price impact in deleveraging situations (Khandani and Lo, 2008; Boyson, Stahel and Stulz, 2008; Stein, 2009). Corporate governance is not just about complying with rules or reporting requirements. Rather it is about internalizing the values, spirit, and purpose behind the rules and is also integral to a company's strategy in creating (or destroying) the shareholders' value. Thus, a sober consideration of the joint importance of governance and abnormal accruals information to separate winners and losers is also in the spirit of Sloan's sagacious advice in the CFA Digest 1/2010: 41: "I believe that using good fundamental analysis to detect accounting distortions by understanding the accounting and the company's strategy and how they fit together will always be an incredibly important source of value-added for the investment management community."

\section{NOTES}

1. The financial reporting industry is a huge and lucrative one. In the Final Report of the Advisory Committee on the Auditing Profession to the U.S. Department of Treasury (2008), the first major study of the U.S. auditing profession, it was reported that the four largest firms audit approximately $98 \%$ of the market capitalization of US public companies. The Big 4 reported approximately $\$ 90$ billion in total revenues. Total revenue reported by the US affiliates of the Big 4 was $\$ 31.2$ billion, of which approximately $\$ 11.8$ billion (37.8\%) was for audits of U.S. public companies.

2. Some may not view the "appropriate" smoothing of earnings to be earnings management. For instance, former Microsoft CFO Greg Maffei, in discussing Microsoft's revenue deferral practices as a possible earnings smoothing device, indicated "unearned revenue is not managed earnings in any way, shape, or form. It's quite the opposite. When people talk about managing earnings, they think you've got some hidden pocket here or there... [but Microsoft's deferred revenue is] entirely visible. It goes in under a set of rules we proclaim to analysts," as quoted in $C F O, 8 / 1999$ (Fink, 1999). 
3. The size and persistence of these abnormal returns from accruals is "pervasive" and generally considered one of the most compelling pieces of evidence against market efficiency (Fama and French, 2008). BusinessWeek in 1/07 reported that "Earnings quality has been Barclays Global Investors' (BGI) single largest source of alpha over the last decade". In Journal of Accounting and Economics survey paper "Accounting Anomalies and Fundamental Analysis: A Review of Recent Research Advances" by Richardson, Tuna and Wysocki (2010), eight (two) out of the top ten papers on anomalies and fundamental analysis that were published in accounting (all) top-tier journals with the highest average citations per year since 1995 relate to the accruals anomaly.

4. In 2007, RiskMetrics acquired IRRC and revamped its data collection methods; consequently, changes were made both in the set of provisions covered and in the definitions of some of the covered provisions. For example, only 18 of the 24 provisions in the G-Index are covered by the 2008 volume of the RiskMetrics governance data.

5. Fama and French (1996) find that many of the anomalies identified in the past largely disappear when their three-factor model in Fama and French (1993) is used to examine them. Kothari (2001) commented that the measurement problem of long-horizon performance measurement is exacerbated when the cumulation period is extended. Kothari (2001) argues that regardless of whether the models by Fama and French (1993) are empirically motivated, it is important to control for factors identified in their models to determine whether the treatment variable or event is generating the abnormal returns.

6. As pointed out by prior studies (e.g. Fama and French, 1993; Carhart, 1997; Larcker et al., 2005, 2007), since the dependent variable is excess returns, the benchmark returns are already included in the computation and additional control variables are not included.

7. In the original GIM (2003), the authors calculated their momentum returns themselves using the procedures of Carhart (1997). It has been found in subsequent studies (e.g. Johnson, Moorman, and Sorescu, 2009) that the results were highly sensitive to the use of either the Carhart's PYIYR factor or Ken French's UMD factor to compute the momentum returns. Specifically, the hedged Democracy-Dictatorship portfolio returns were either reduced or rendered statistically insignificant when the $U M D$ factor is used. Again, to be conservative, I use the factor $U M D$ that is biased against my findings.

8. Consistent with prior literature (e.g. Francis et al., 2005) and throughout this section in the computation of the measures of earnings quality as proxied by abnormal accruals, I winsorize the extreme values of the distribution of each variable in the regression model to the 1 and 99 percentiles to ensure that the results are not driven by outliers.

9. Hribar and Nichols (2007) pointed out that using unsigned or absolute abnormal accruals as a measure of earnings management will increase the expected value of absolute abnormal accruals due to a lack of fit in the estimation of abnormal accruals, and hence can bias tests in favor of rejecting the null hypothesis of earnings management. They propose the use of signed abnormal accruals as a more conservative test of earnings management, where significant results are obtained in spite of the noise in the estimation of abnormal accruals. Dechow and Ge (2006) also commented that the sign of the accruals is important: "earnings persistence is affected by both the magnitude and sign of accruals." 
10. Alford and Zmijewski (1994) report that there is violation and extension of the mandatory SEC Form 10-K filing requirement for around $20 \%$ of their sample over the period 1978-1985, and prior studies such as Sloan (1996) ranked their sample firms into deciles based on the magnitude of their scaled abnormal accruals four months after the fiscal year end, arguing that by this time, almost all firms' financial statements are publicly available. However, as pointed out by Green, Hand, and Soliman (2009), it is increasingly common for firms to voluntarily report both earnings and cash flows at their quarterly and annual earnings announcements, well prior to the mandatory 10-Q and 10-K filing dates. Real-time data providers such as Compustat and FactSet have also increased the amount of detailed information they provide to their clients and the speed at which they provide it. With this contemporary view, Green et al. (2009) used three months after the fiscal year end to do their ranking. As a robustness check, I find that my results are not quantitatively or qualitatively affected when I use four months after the fiscal year end in the ranking exercise; in fact, some of the key results are stronger and I report the more conservative set of results.

11. Collins and Hribar (2002) use an alternative measure of accruals that is based on the statement of cash flows, rather than from the balance sheet approach advocated in Sloan (1996). They argue that firms that have undergone a merger and acquisition (or divestiture) are more likely to have high (or low) accruals. Since the subsequent stock returns of firms involved in M\&As tend to be below average, high accruals may be associated with poor future returns. They term this as the "non-articulation problem." Ball and Shivakumar (2008) argued forcefully that the results in Teoh, Welch and Wong (1998a, 1998b) are due to this non-articulation problem, and doubt the use of abnormal accruals in studies that involve large transactional events, such as an IPO/SEO. My study does not involve the setting of examining earnings quality around a major transactional event. Further robustness checks using the cash flow approach advocated by Collins and Hribar (2002) do not affect my results qualitatively either.

12. Instead of $T A C C$, some studies use $W A C C$, or working capital accrual, which is computed without subtracting depreciation. As pointed out by Richardson et al. (2005), there is considerable subjectivity involved in selecting an amortization schedule for PP\&E. The depreciation/ amortization method, the useful life, and the salvage value are all subjective decisions that impact this accrual category. PP\&E are subject to periodic write-downs when they are determined to have been impaired. The estimation of the amount of these impairments involves great subjectivity. For example, the well publicized accounting scandal at WorldCom involved billions of dollars of operating costs that were aggressively capitalized as PP\&E. I find that my results are not affected qualitatively by using $T A C C$ or $W A C C$, and I report $T A C C$ in the Empirical Results Section for the reasons highlighted above and for comparability with other studies which mostly use TACC (e.g. see the comprehensive survey by Dechow et al., 2009).

13. Allen et al. (2010) further argued that their use of current accruals in their empirical analysis can help them to mitigate concerns about loss of power from the omission of longer-term reversals.

14. Interestingly, this could be a possible reason why none of the prior literature had examined the joint importance of governance and abnormal accruals in returns predictability; even though the research methodology - essentially sorting the firms along the two dimensions of performance measures - is not too complicated. Together with the common knowledge that governance and 
accounting quality might be positively correlated with each another (the Pearson correlation coefficient between the G-Index and abnormal accruals in Dechow and Dichev (2002) is significantly positive at 0.014 ), some of the unique information in the unique pairing of the signals is hidden in the statistical averages. Simply controlling for corporate governance as an independent variable in multiple regression models might not be appropriate since the regression orthogonalizes the independent variables with respect to one another, and any unique information that comes from the combination of both is not captured in the coefficients.

15. Sorting the firms first by governance and then by abnormal accruals (AA), or first by AA and then by governance, gives basically the same qualitative results. I also conduct sorts based on the most extreme governance and AA i.e. firms with G-Index score of 5 and below (14 and above) are classified as Democracy (Dictatorship), while firms with AA Score of 1 (10) are classified as Low $A A$ (High $A A)$; this also does not significantly affect qualitatively the results. I stick with the extended sample classification of Democracy firms as having a G-Index score of 7 and Low $A A$ (High AA) firms as having an AA Score of 3 and below (8 and above) since the portfolio returns of these groups are economically similar in magnitude in the original GIM (2003) and Sloan (1996) studies, and it ensures that there is a reasonable number of firms in each of the twodimensional sorted portfolios to increases the degrees of freedom so as to yield a more reliable statistical interpretation of the results. I also argue that there is a heightened increase in attention on corporate governance and the abnormal accruals signal, especially after the post-GIM and post-Sloan-TAR period, and investors will inevitably allocate their resources as they analyze nearDemocracy-Dictatorship and slightly-less-extreme AA firms. Note in particular that, as one of my key tests is to examine whether isolating Democracy-Low AA firms will enhance significantly the governance effects on returns (H1b), such a sorting and re-classification is biased against my findings.

16. In a further robustness check, defining $A C C R E V_{\mathrm{t}+1}$ as the change in abnormal accruals (measured as the residual in Dechow and Dichev (2002) model) from period $t$ to period $t+l$ does not change my results. The abnormal returns remain at $10.7 \%$ per year but are more significant (t-statistics 2.58). Thus, I report the more conservative results.

17. The remaining $57 \%$ of the sample have a positive monthly alpha of $0.569 \%$, or $6.8 \%$ per year, although they are no longer significant.

18. See http://heritage.coca-cola.com/ for a heritage timeline of Coca-Cola.

19. Interestingly, billionaire investor Warren Buffett purchased $7 \%$ of Coca-Cola for $\$ 1$ billion for his listed investment holding company Berkshire Hathaway in 1988, and added 1.2\% along the way at $\$ 0.3$ billion, seemingly demonstrating the sophistication to exploit the joint importance of governance and abnormal accruals to generate outsized returns. Of course, he remains a rare exception - and also an inspiration that the results in this paper could be implementable. Buffett's $\$ 1.3$ billion investment cost in Coca-Cola has since grown nearly 10 -fold to around $\$ 11$ billion. 


\section{REFERENCES}

Ahmed, A.S., Takeda, C., and Thomas, S. (1999). "Bank Loan Loss Provisions: A Re-examination of Capital Management, Earnings Management and Signalling Effects," Journal of Accounting and Economics, 28: 1-25.

Alford, A.W., Jones, J., and Zmijewski, M.E. (1994) "Extensions and Violations of the Statutory SEC Form 10-K Filing Requirements," Journal of Accounting and Economics, 17: 229-254.

Allen, E., Larson, C., and Sloan, R.G. (2010). “Accrual Reversals, Earnings and Stock Returns,” working paper.

Amir, E. and Lev, B. (1996). "Value-Relevance of Nonfinancial Information: The Wireless Communications Industry," Journal of Accounting and Economics, 22: 3-30.

Ang, J.S., Cole, R.A., and Lin, J.W. (2000). “Agency Costs and Ownership Structure,” Journal of Finance, 55(1): 81-106.

Arya, A., Glover, J.C., and Sunder, S. (2003). "Are Unmanaged Earnings Always Better for Shareholders," Accounting Horizons (Supplement): 111-116,

Ball, R. and Shivakumar, L. (2008). "Earnings Quality at Initial Public Offerings," Journal of Accounting and Economics, 45: 324-349.

Ball, R., Jayaraman, S., and Shivakumar, L. (2010). "Audited Financial Reporting and Voluntary Disclosure as Complements: A Test of the Confirmatory Hypothesis," working paper.

Balsam, S. (1998). "Discretionary Accounting Choices and CEO Compensation," Contemporary Accounting Research, 15: 229-252.

Barth, M.E., Elliott, J.A., and Finn, M.W. (1999). "Market Rewards Associated with Patterns of Increasing Earnings," Journal of Accounting Research, 37(2): 387-413.

Barth, M.E., Beaver, W.H., and Landsman, W.R. (2001). "The Relevance of Value Relevance Literature for Financial Accounting Standard-Setting: Another View," Journal of Accounting and Economics, 29: 1-51.

Barton, J., Hansen, T.B., and Pownall, G. (2010). "Which Performance Measures Do Investors Around the World Value the Most - and Why?" Accounting Review, 85(3): 753-789.

Bartov, E., Givoly, D., and Hayn, C. (2002). "The Rewards to Meeting or Beating Earnings Expectations," Journal of Accounting and Economics, 33(2): 173-204.

Bartov, E. and Mohanram, P. (2004). "Private Information, Earnings Manipulations, and Executive Stock Option Exercises," Accounting Review, 79(4): 889-920. 
Beasley, M.S. (1996). "An Empirical Analysis of the Relation between the Board of Director Composition and Financial Statement Fraud," Accounting Review, 71: 443-465.

Beaver, W.H. Eger, C., Ryan, S., and Wolfson, M. (1989). "Financial Reporting and the Structure of Bank Share Prices,” Journal of Accounting Research, 27: 157-178.

Beaver, W.H. and Engel, E.E. (1996). Discretionary Behavior with Respect to Allowances for Loan Losses and the Behavior of Stock Prices," Journal of Accounting and Economics, 22: 177-206.

Bebchuk, L.A., Cohen, A., and Farrell, K.A. (2009). "What Matters in Corporate Governance?" Review of Financial Studies, 22(2): 783-827.

Bebchuk, L.A., Cohen, A., and Wang, C.Y. (2010). "Learning and the Disappearing Association between Governance and Returns," working paper.

Becker, C.L., DeFond, M.L., Jiambalvo, J., and Subramanyam, K.R. (1998). "The Effect of Audit Quality on Earnings Management," Contemporary Accounting Research, 15(1): 1-24.

Beneish, M.D., Lee, M.C., and Tarpley, R.L. (2001). "Contextual Fundamental Analysis through the Prediction of Extreme Returns," Review of Accounting Studies, 6: 165-189.

Bergstresser, D. and Philippon, T. (2006). "CEO Incentives and Earnings Management," Journal of Financial Economics, 80(3): 511-529.

Bertrand, M. and Mullainathan, S. (2003). "Enjoying the Quiet Life? Corporate Governance and Managerial Preferences," Quarterly Journal of Economics, 111(5): 1043-1075.

Boehmer, E., Jones, C.M., and Zhang X. (2009). "Shackling Short-Sellers: The 2008 Shorting Ban,” working paper.

Bowen, R.M., Rajgopal, S., and Venkatachalam, M. (2008). "Accounting Discretion, Corporate Governance and Firm Performance," Contemporary Accounting Research, 25(2): 351-405.

Boyson, N.M., Stahel, C.W., and Stulz, R.M. (2008). "Why Do Hedge Funds' Worst Returns Cluster? Common Liquidity Shocks vs. Contagion," working paper.

Bradshaw, M.T., Richardson, S.A., and Sloan, R.G. (2001). "Do Analysts and Auditors Use Information in Accruals," Journal of Accounting Research, 39(1): 45-74.

Brockman (2000). "The Greatest Inventions of the Past 2,000 Years. Simon \& Schuster.

Brown, L.D. and Caylor, M.L. (2006). "Corporate Governance and Firm Valuation," Journal of Accounting and Public Policy, July-Aug: 409-434.

Burns, N. and Kedia, S. (2006). "The Impact of Performance-based Compensation on Misreporting," Journal of Financial Economics, 79(1): 35-67. 
Bushman, R.M. and Smith, A.J. (2001). "Financial Accounting Information and Corporate Governance," Journal of Accounting and Economics, 32: 237-333.

Bushman, R.M., Chen, Q., Engel, E., and Smith, A. (2004). "Financial Accounting Information, Organizational Complexity and Corporate Governance Systems," Journal of Accounting and Economics, 37: 167-201.

Carhart, M.M. (1997). “On Persistence in Mutual Fund Performance,” Journal of Finance, 52: 57-82.

Caylor, M.L. (2010). "Strategic Revenue Recognition to Achieve Earnings Benchmark," Journal of Accounting and Public Policy, 29: 82-95.

Chan, K., Chan, K.C., Jegadeesh, N., and Lakonishok, J. (2006). "Earnings Quality and Stock Returns," Journal of Business, 79: 1041-82.

Chaney, P.K., Jeter, D.C., and Lewis, C.M. (1998). "The Use of Accruals in Income Smoothing: A Permanent Earnings Hypothesis," Advances in Quantitative Analysis of Finance and Accounting, 6: 103-135.

Chen, K., and J. Lee (1995). "Executive Bonus Plans and Accounting Trade-offs: The Case of the Oil and Gas Industry, 1985-1986," Accounting Review, 70(1): 91-111.

Cheng, Q. and Warfield, T.D. (2005) "Equity Incentives and Earnings Management," Accounting Review, 80(2): 441-476.

Christie, A.A. and Zimmerman, J.L. (1994). "Efficient and Opportunistic Choices of Accounting Procedures: Corporate Control Contests," Accounting Review, 69(4): 539-66.

Cohen, D.A., Dey, A., and Lys, T.Z. (2008). "Real and Accrual-based Earnings Management in the Pre and Post SOX Periods," Accounting Review, 83(3): 757-787.

Collins, D.W. and DeAngelo, L. (1990). "Accounting Information and Corporate Governance: Market and Analyst Reactions to Earnings of Firms Engaged in Proxy Contests," Journal of Accounting and Economics, 13: 213-247.

Collins, D.W., Maydew, E.L., and Weiss, I.S. (1997). "Changes in the Value-Relevance of Earnings and Book Values over the Past Forty Years," Journal of Accounting and Economics, 24: 39-67.

Collins, D.W. and Hribar, P. (2002). "Errors in Estimating Accruals: Implications for Accounting Research," Journal of Accounting Research, 40: 105-134.

Cooper, M.J., Gulen, H., and Schill, M.J. (2008). "Asset Growth and the Cross-Section of Stock Returns," Journal of Finance, 63: 1609-1651. 
Core, J.E., Gray, W.R., and Rusticus, T.O. (2006). "Does Weak Governance Cause Weak Stock Returns? An Examination of Firm Operating Performance and Investors' Expectations," Journal of Finance, 61: 655-687.

Core, J.E. (2006). "Discussion of An Analysis of the Theories and Explanations Offered for the Mispricing of Accruals and Accruals Components," Journal of Accounting Research, 44(2): 341-350.

Cornett, M.M., Marcus, A.J., and Tehranian, H. (2008). "Corporate Governance and Pay-forPerformance: The Impact of Earnings Management," Journal of Financial Economics, 86: 279-305.

Cremers, K.J.M. and Nair, V.B. (2005). “Governance Mechanisms and Equity Prices,” Journal of Finance, 60: 2859-2894.

Daines, R.M., Gow, I.D., and Larcker, D.F. (2010). "Rating the Ratings: How Good Are the Commercial Governance Ratings?” Journal of Financial Economics, 98: 439-461.

DeAngelo, L.E. (1988). "Managerial Competition, Information Costs, and Corporate Governance," Journal of Accounting and Economics, 10: 3-36.

DeAngelo, H., DeAngelo, L., and Skinner, D.J. (1994). "Accounting Choice in Troubled Companies," Journal of Accounting and Economics, 17(1-2): 113-143.

Dechow, P.M. (1994). "Accounting Earnings and Cash Flows as Measures of Firm Performance: The Role of Accounting Accruals,” Journal of Accounting and Economics, 18: 3-42.

Dechow, P.M., Sloan, R.G., and Sweeney, A.P. (1995). "Detecting Earnings Management," Accounting Review. 70(2): 193-225.

------, (1996). "Causes and Consequences of Earnings Manipulations: An Analysis of Firms Subject to Enforcement Actions by the SEC," Contemporary Accounting Research. 13(1): 1-36.

Dechow, P.M. and Skinner, D.J. (2000). "Earnings Management: Reconciling the Views of Accounting Academics, Practitioners, and Regulators," Accounting Horizons, 14(2): 235-250.

Dechow, P.M. and Dichev, I.D. (2002). "The Quality of Accruals and Earnings: The Role of Accrual Estimation Errors," Accounting Review, 77 (Supplement): 35-59.

Dechow, P.M. and Ge, W. (2006). "The Persistence of Earnings and Cash Flows and the Role of Special Items: Implications for the Accrual Anomaly," Review of Accounting Studies, 11: 253-296.

Dechow, P.M., Richardson, S.A., and Sloan, R.G. (2008). "The Persistence and Pricing of the Cash Component of Earnings," Journal of Accounting Research, 46(3): 537-566.

Dechow, P.M., Ge, W., and Schrand, C. (2010). "Understanding Earnings Quality: A Review of the Proxies, Their Determinants, and their Consequences," Journal of Accounting and Economics, 50: 344-401. 
DeFond, M.L. and Park, C.W. (1997). "Smoothing Income in Anticipation of Future Earnings," Journal of Accounting and Economics, 23: 115-139.

DeFond, M.L. and Subramanyam, K.R. (1998). “Auditor Changes and Discretionary Accruals, Journal of Accounting and Economics, 25: 35-67.

Demsetz, H. and Lehn, K. (1985). “The Structure of Corporate Ownership: Causes and Consequences,” Journal of Political Economy, XCIII: 1155-1177.

Demski, J.S. (1998). "Performance Measure Manipulation," Contemporary Accounting Research, 15: 261-285.

Demski, J.S., Frimor, H., and Sappington, D.E.M. (2004). "Efficient Manipulation in a Repeated Setting," Journal of Accounting Research, 42(1): 31-49.

Desai, H., Rajgopal, S., and Venkatachalam, M. (2004). "Value-Glamour and Accruals Mispricing: One Anomaly or Two?" Accounting Review, 79: 355-85.

Desai, H., Hogan, C.E., and Wilkins, M.S. (2006). "The Reputational Penalty for Aggressive Accounting: Earnings Restatements and Management Turnover," Accounting Review, 81: 83-112.

Djankov, S., La Porta, R., Silanes, F. and Shleifer, A. (2008). "The Law and Economics of SelfDealing," Journal of Financial Economics, 88: 430-465.

Fairfield, P.M., Whisenant, J.S. and Yohn, T.L. (2003). "Accrued Earnings and Growth: Implications for Future Profitability and Market Mispricing," Accounting Review, 78: 353-371.

Fairfield, P.M. (2006). "Discussion of the Persistence of Earnings and Cash Flows and the Role of Special Items: Implications for the Accrual Anomaly," Review of Accounting Studies, 11: 297-303.

Fama, E.F. and French, K.R. (1993). "Common Risk Factors in the Returns on Bonds and Stocks," Journal of Financial Economics: 3-56.

------, (1995). "Size and Book-to-Market Factors in Earnings and Returns," Journal of Finance, 1: $131-155$.

-----, (1996). “Multifactor Explanations of Asset Pricing Anomalies,” Journal of Finance, 51: 55-84.

------, (2008). “Dissecting Anomalies,” Journal of Finance, 63: 1653-1678.

Farrell, K.A. and Whidbee, D.A. (2003). "The Impact of Firm Performance Expectations on CEO Turnover and Replacement Decisions," Journal of Accounting and Economics, 36(1-3): 165-196.

Fink (1999). “Smooth Operator," CFO, (August 1) 15(8): 34-40. 
Francis, J.R. and Schipper (1999). "Have Financial Statements Lost their Relevance?” Journal of Accounting Research, 37: 319-352.

Francis, J.R., LaFond, R., Olsson, P.M., and Schipper, K. (2004). "Cost of Equity and Earnings Attributes," Accounting Review, 79: 967-1010.

------, (2005). “The Market Pricing of Accruals Quality,” Journal of Accounting and Economics, 37: 295-327.

García, J.M., García, B.O., and Penalva, F. (2009). "Accounting Conservatism and Corporate Governance," Review of Accounting Studies, 14: 161-201.

Gaver, J.J., Gaver, K., and Austin, J. (1995). "Additional Evidence on Bonus Plans and Income Management," Journal of Accounting and Economics, 19(1): 3-28.

Ghosh, A., Gu, Z., and Jain, P.C. (2005). "Sustained Earnings and Revenue Growth, Earnings Quality, and Earnings Response Coefficients," Review of Accounting Studies, 10: 33-57.

Ghosh, D. and Olsen, L. (2009). "Environmental Uncertainty and Managers' Use of Discretionary Accruals," Accounting, Organizations and Society, 34: 188-205.

Goel, A.M. and Thakor, A.V. (2003). “Why Do Firms Smooth Earnings?” Journal of Business, 76(1): 151-193.

Gompers, P., Ishii, J., and Metrick, A. (2003). "Corporate Governance and Equity Prices," Quarterly Journal of Economics, 118: 107-155.

-----, (2010). "Extreme Governance: An Analysis of Dual-Class Firms in the United States," Review of Financial Studies, 23(3): 1051-1088.

Graham, J.R., Harvey, C.R., and Rajgopal, S. (2005). “The Economic Implications of Corporate Financial Reporting," Journal of Accounting and Economics, 40: 3-73.

Green, J., Hand, J.R.M., and Soliman, M.T. (2009). “The Demise of the Accruals Anomaly,” working paper.

Guay, W.R., Kothari, S.P., and Watts, R.L. (1996). “A Market Based Evaluation of Discretionary Accruals Models," Journal of Accounting Research, 34(Supplement): 83-105.

Guay, W.R. (2008). "Discussion of "Accounting Discretion, Corporate Governance, and Firm Performance." Contemporary Accounting Research, 25(2): 407-413.

Guidry, F., Leone, A.J. and Rock, S. (1999). "Earnings-Based Bonus Plans and Earnings Management by Business-Unit Managers," Journal of Accounting and Economics, 26(1-3): 113-142. 
Habib, M.A. (2007). “' 'Benchmark-Beating' as Evidence of Earnings Management: Review of the Literature," working paper.

Healy, P.M. (1985). "The Effect of Bonus Schemes on Accounting Decisions," Journal of Accounting \& Economics, 7(3): 85-107.

Healy, P.M. and Palepu, K.G. (1993). “The Effect of Firms' Financial Disclosure Strategies on Stock Prices," Accounting Horizons, 7(1): 1-11.

Healy, P.M. (1996). "Discussion of a Market-Based Evaluation of Discretionary Accruals Models," Journal of Accounting Research, 34 (Supplement): 107-115.

------, (1999). "Discussion of Earnings-Based Bonus Plans and Earnings Management by BusinessUnit Managers," Journal of Accounting and Economics, 26(1-3): 143-147.

Healy, P.M. and Whalen, J.M. (1999). "A Review of Earnings Management Literature and its Implications for Standard Setting," Accounting Horizons, 13(4): 365-384.

Hermalin, B.E. and Weisbach, M.S. (2003). "Boards of Directors as Endogenously Determined Institutions: A Survey of the Economic Literature," Economic Policy Review, 9: 7-26.

Holthausen, R.W. and Leftwich, R.W. (1983). "The Economic Consequences of Accounting Choice: Implications of Costly Contracting and Monitoring," Journal of Accounting and Economics, 5: 77118.

Holthausen, R.W. (1990). "Accounting Method Choice: Opportunistic Behavior, Efficient Contracting and Information Perspectives," Journal of Accounting and Economics, 12: 207-218.

Holthausen, R.W. and Watts, R.L. (2001). "The Value Relevance of the Value-Relevance Literature for Financial Accounting Standard Setting," Journal of Accounting and Economics, 31: 3-75.

Hribar, P. and Nichols, C. (2007). "The Use of Unsigned Earnings Quality Measures in Tests of Earnings Management,” Journal of Accounting Research, 45(5): 1017-1053.

Jensen, M.C. and Meckling, W.H. (1976). "Theory of the Firm: Managerial Behavior, Agency Costs and Ownership Structure," Journal of Financial Economics, 3: 305-360.

Jensen, M.C. (1986). “Agency Costs of Free Cash Flow, Corporate Finance, and Takeovers," American Economic Review, 76(2): 323-329.

Jiang, X. (2008). "Beating Earnings Benchmark and the Cost of Debt, "Accounting Review, 83(2): $377-416$

Johnson, S.A., Moorman, T.C., and Sorescu, S. (2009). "A Re-examination of Corporate Governance and Equity Prices,” Review of Financial Studies, 22(11): 4753-86. 
Jones, J.J. (1991). “Earnings Management during Import Relief Investigations,” Journal of Accounting Research, 29: 193-228.

Jones, C.M. and Lamont, O.A. (2002). "Short-Sale Constraints and Stock Returns," Journal of Financial Economics, 66: 207-239.

Joos, P. (2003). "Discussion of How Representative are Firms that are Cross-Listed in the United States, An Analysis of Accounting Quality,” Journal of Accounting Research, 41: 387-396.

Kasznik, R. and McNichols, M.F. (2002). "Does Meeting Earnings Expectations Matter? Evidence from Analyst Forecast Revisions and Share Prices," Journal of Accounting Research, 40(3): 727-759.

Khandani, A.E. and Lo, A. (2008). "What Happened to the Quants in August 2007? Evidence from Factors and Transactions Data," working paper.

Kinney, W.R. (2002). "Discussion of the Relation between Auditors' Fees for Non-Audit Services and Earnings Management," Accounting Review, 77 (Supplement): 107-114.

Klein, A. (2002). "Audit Committee, Board of Director Characteristics, and Earnings Management," Journal of Accounting and Economics, 33: 375-400.

Koonce, L. and Lipe, M.G. (2010). "Earnings Trend and Performance Relative to Benchmarks: How Consistency Influences Their Joint Use,” Journal of Accounting Research, 48(4): 859-884.

Kothari, S.P. (2001). "Capital Markets Research in Accounting," Journal of Accounting and Economics, 31: 105-231.

Kraft, A., Leone, A.J., and Wasley, C. (2006). "Discussion of an Analysis of the Theories and Explanations Offered for the Mispricing of Accruals and Accruals Components," Journal of Accounting Research, 44(2): 297-339.

La Porta, R., Silanes, F.L., Shleifer, A., and Vishny, R. (2000). "Investor Protection and Corporate Governance," Journal of Financial Economics, 58: 3-27.

Lakonishok, J., Shleifer, A., and Vishny, R. (1994). “Contrarian Investment, Extrapolation, and Risk,” Journal of Finance, 49: 1541-1578.

Lang, M., Raedy, J.S., and Yetman, M.H. (2003). "How Representative are Firms that are CrossListed in the United States, An Analysis of Accounting Quality," Journal of Accounting Research, 41: 363-386.

Larcker, D.F., Richardson, S.A., and Tuna, I. (2005). "How Important Is Corporate Governance," working paper. 
., (2007). "Corporate Governance, Accounting Outcomes, and Organizational Performance," Accounting Review, 82(4): 963-1008.

Larcker, D.F. and Rusticus, T.O. (2010). "On the Use of Instrumental Variables in Accounting Research," Journal of Accounting and Economics, 49: 186-205.

Lee, C. (2001). "Market Efficiency and Accounting Research: A Discussion of "Capital Market Research in Accounting' by S.P. Kothari," Journal of Accounting and Economics, 31: 233-253.

Lee, J., Li, Y., and Yue, H. (2006). "Performance, Growth, and Earnings Management," Review of Accounting Studies, 11: 305-334.

Lev, B. and Zarowin, P. (1999). "The Boundaries of Financial Reporting and How to Extend Them," Journal of Accounting Research, 37: 353-385.

Lev, B. and Nissim, D. (2006). "The Persistence of the Accruals Anomaly," Contemporary Accounting Research, 23(1): 193-226.

Lo, A. (2008). "Earnings Management and Earnings Quality," Journal of Accounting \& Economics, 45: 350-357.

Louis, H. and Robinson, D. (2005). "Do Managers Credibly use Accruals to Signal Private Information? Evidence from the Pricing of Discretionary Accruals around Stock Splits," Journal of Accounting and Economics, 39: 361-380.

Malmquist, D.H. (1990). "Efficient Contracting and the Choice of Accounting Method in the Oil and Gas Industry," Journal of Accounting and Economics, 12: 173-205.

Marquardt, C. and Wiedman, C. (2005). "How are Earnings Managed? An Examination of Specific Accruals," Contemporary Accounting Research, 21(2): 461-491

Matsunaga, S.R. (1995). "The Effects of Financial Reporting Costs on the Use of Employee Stock Options," Accounting Review, 70(1): 1-26.

Matsunaga, S.R. and Park, C.W. (2001). "The Effect of Missing a Quarterly Eamings Benchmark on the CEO`s Annual Bonus," Accounting Review, 16(3): 313-332.

McNichols, M.F. and Wilson, P. (1988). "Evidence of Earnings Management from the Provision for Bad Debts," Journal of Accounting Research, 26(Supplement): 1-31.

McNichols, M.F. (2000). "Research Design Issues in Earnings Management Studies," Journal of Accounting and Public Policy, 19: 313-345.

., (2002). "Discussion of the Quality of Accruals and Earnings: The Role of Accrual Estimation Errors," Accounting Review, 77(Supplement): 61-69. 
McNichols, M.F. and Stubben, S.R. (2008). "Does Earnings Management Affect Firms' Investment Decisions?" The Accounting Review, 83: 1571-1603,

Menon, K. and Williams, D.D. (2004), "Former Audit Partners and Abnormal Accruals," Accounting Review, 79(4): 1095-118.

Mitchell, M., Pedersen, L.H., and Pulvino, T. (2007). "Slow Moving Capital," American Economic Review (Papers and Proceedings), 97: 215-220.

Moore, M.L. (1973). "Management Changes and Discretionary Accounting Decisions," Journal of Accounting Research, 11: 100-107.

Murphy, K.J. and Zimmerman, J.L. (1993). "Financial Performance Surrounding CEO Turnover," Journal of Accounting and Economics, 16: 273-315.

Newman, P. (1988). "Discussion of an Explanation of Income Smoothing," Journal of Accounting Research, 26: 140-143.

Peasnell, K.V., Pope, P.F., and Young, S. (2005). "Board Monitoring and Earnings Management: Do Outside Directors Influence Abnormal Accruals?” Journal of Business Finance and Accounting, 32: 1311-1346.

Perry, S.E. and Williams, T.H. (1994). "Earnings Management Preceding MBO Offers," Journal of Accounting and Economics, 18: 157-179.

Pourciau, S. (1993). "Earnings Management and Non-Routine Executive Changes," Journal of Accounting and Economics, 16: 317-336.

Richardson, S.A., Sloan, R.G., Soliman, M.T., and Tuna, I. (2005). "Accrual Reliability, Earnings Persistence, and Stock Prices," Journal of Accounting and Economics, 39: 437-485.

........., (2006). "The Implications of Accounting Distortions and Growth for Accruals and Profitability," Accounting Review, 81(3): 713-743.

Richardson, S.A., Tuna, I., and Wysocki, P. (2010). "Accounting Anomalies and Fundamental Analysis," Journal of Accounting and Economics, 50: 410-454.

Schipper, K. (1989). “Commentary on Earnings Management,” Accounting Horizons, (December): 91-102.

Schipper, K. and Vincent, L. (2003). “Earnings Quality,” Accounting Horizons, 17: 97-110.

Shevlin, T. (1996). “The Value-Relevance of Nonfinancial Information: A Discussion,” Journal of Accounting and Economics, 22: 31-42. 
Shleifer, A. and Vishny, R. (1988). "Value Maximization and the Acquisition Process," Journal of Economic Perspectives, 2(1): 7-20.

(1989). "Managerial Entrenchment: The Case of Manager-Specific Investments," Journal of Financial Economics, 25: 123-139.

(1997). “The Limits of Arbitrage,” Journal of Finance, 52(1): 93-117.

Skinner, D. and Sloan, R.G. (2002). "Earnings Surprises, Growth Expectations and Stock Returns, or Don't Let an Earnings Torpedo Sink Your Portfolio," Review of Accounting Studies, 7: 289-312.

Skypala (2009). “ 'Quant Creator' Says Now Is a Good Time to be Different," Financial Times, January 26: 4.

Sloan, R.G. (1996). "Do Stock Prices Fully Reflect Information in Accruals and Cash Flows about Future Earnings?” Accounting Review, 71(3): 289-315.

........., (2001). "Financial Accounting and Corporate Governance: A Discussion," Journal of Accounting and Economics, 32: 335-347.

(2001). "Discussion of 'Contextual Fundamental Analysis' through the Prediction of Extreme Returns," Review of Accounting Studies, 6: 191-195.

Smith, A. (1993). "Earnings and Management Incentives," Journal of Accounting and Economics, 16: 337-347.

., (1993). "A Perspective on Accounting-Based Debt Covenant Violations," Accounting Review, 68(2): 289-303.

Sorensen, E.H., Hua, R., and Qian, E. (2005). "Contextual Fundamentals, Models, and Active Management," Journal of Portfolio Management, (Fall): 23-36.

Stein, J.C. (2009). “Sophisticated Investors and Market Efficiency (Presidential Address)," Journal of Finance, 64(4): 1517-1548.

Subramanyam, K.R. (1996). "The Pricing of Discretionary Accruals," Journal of Accounting and Economics, 22(1-3): 249-281.

Sweeney, A.P. (1994). "Debt-Covenant Violations and Managers' Accounting Responses," Journal of Accounting and Economics, 17: 281-308.

The Department of the Treasury, (2008). Final Report of the Advisory Committee on the Auditing Profession to the U.S. Department of Treasury.

Titman, S., Wei, K.C., and Xie, F. (2004). “Capital Investments and Stock Returns,” Journal of Financial \& Quantitative Analysis, 39: 677-700. 
Trammell, S. (2010). “Illuminating the Accruals Anomaly,” CFA Digest, (Jan-Feb): 38-41.

Trueman, B. and Titman, S. (1988). “An Explanation of Income Smoothing,” Journal of Accounting Research, 26: 127-139.

Tucker, J.W. and Zarowin, P.A. (2006). "Does Income Smoothing Improve Earnings Informativeness," Accounting Review, 81(1): 251-270.

Wahlen, J.M. (1994). "The Nature of Information in Commercial Loan Loss Disclosures," Accounting Review, 69: 455-478.

Watts, R.L. and Zimmerman, J.L. (1978). "Towards a Positive Theory of the Determination of Accounting Standards," Accounting Review, 53(1): 112-134.

.........., (1986). Positive Theory of Accounting. Englewood Cliffs, NJ: Prentice-Hall, Inc.

(1990). "Positive Accounting Theory: A Ten-Year Perspective," Accounting Review, 65(1): $131-156$.

Weisbach, M.S. (1988). “Outside Directors and CEO Turnover,” Journal of Financial Economics, 20: 431-460.

Xie, H. (2001). “The Mispricing of Abnormal Accruals,” Accounting Review, 76(3): 357-373.

Zhang, F. (2007). "Accruals, Investment, and the Accruals Anomaly," Accounting Review, 82: 13331364. 